\title{
Climate seasonality limits leaf carbon assimilation and wood productivity in tropical forests
}

Fabien H. Wagner ${ }^{1}$, Bruno Hérault ${ }^{2}$, Damien Bonal ${ }^{3}$, Clément Stahl $^{4,5}$, Liana O. Anderson ${ }^{6}$, Timothy R. Baker ${ }^{7}$, Gabriel Sebastian Becker $^{8}$, Hans Beeckman ${ }^{9}$, Danilo Boanerges Souza ${ }^{10}$, Paulo Cesar Botosso ${ }^{11}$, David M. J. S. Bowman ${ }^{12}$, Achim Bräuning ${ }^{13}$, Benjamin Brede ${ }^{14}$, Foster Irving Brown ${ }^{15}$, Jesus Julio Camarero ${ }^{16,17}$, Plínio Barbosa Camargo $^{18}$, Fernanda C. G. Cardoso ${ }^{19}$, Fabrício Alvim Carvalho ${ }^{20}$, Wendeson Castro $^{21}$, Rubens Koloski Chagas $^{22}$, Jérome Chave ${ }^{23}$, Emmanuel N. Chidumayo ${ }^{24}$, Deborah A. Clark ${ }^{25}$, Flavia Regina Capellotto Costa $^{26}$, Camille Couralet ${ }^{9}$, Paulo Henrique da Silva Mauricio ${ }^{15}$, Helmut Dalitz ${ }^{8}$, Vinicius Resende de Castro $^{27}$, Jaçanan Eloisa de Freitas Milani ${ }^{28}$, Edilson Consuelo de Oliveira ${ }^{29}$, Luciano de Souza Arruda ${ }^{30}$, Jean-Louis Devineau ${ }^{31}$, David M. Drew ${ }^{32}$, Oliver Dünisch ${ }^{33}$, Giselda Durigan ${ }^{34}$, Elisha Elifuraha ${ }^{35}$, Marcio Fedele $^{36}$, Ligia Ferreira Fedele ${ }^{36}$, Afonso Figueiredo Filho ${ }^{37}$, César Augusto Guimarães Finger ${ }^{38}$, Augusto César Franco ${ }^{39}$, João Lima Freitas Júnior ${ }^{21}$, Franklin Galvão ${ }^{28}$, Aster Gebrekirstos ${ }^{40}$, Robert Gliniars ${ }^{8}$, Paulo Maurício Lima de Alencastro Graça ${ }^{41}$, Anthony D. Griffiths ${ }^{42,43}$, James Grogan ${ }^{44}$, Kaiyu Guan ${ }^{45,46}$, Jürgen Homeier ${ }^{47}$, Maria Raquel Kanieski $^{48}$, Lip Khoon Kho ${ }^{49}$, Jennifer Koenig ${ }^{43}$, Sintia Valerio Kohler ${ }^{37}$, Julia Krepkowski ${ }^{13}$, José Pires Lemos-Filho $^{50}$, Diana Lieberman ${ }^{51}$, Milton Eugene Lieberman ${ }^{51}$, Claudio Sergio Lisi ${ }^{36,52}$, Tomaz Longhi Santos $^{28}$, José Luis López Ayala ${ }^{53}$, Eduardo Eijji Maeda ${ }^{54}$, Yadvinder Malhi ${ }^{55}$, Vivian R. B. Maria ${ }^{36}$, Marcia C. M. Marques ${ }^{19}$, Renato Marques ${ }^{56}$, Hector Maza Chamba ${ }^{57}$, Lawrence Mbwambo ${ }^{58}$, Karina Liana Lisboa Melgaço ${ }^{26}$, Hooz Angela Mendivelso ${ }^{16,17}$, Brett P. Murphy ${ }^{59}$, Joseph J. O'Brien ${ }^{60}$, Steven F. Oberbauer ${ }^{61}$, Naoki Okada ${ }^{62}$, Raphaël Pélissier ${ }^{63,64}$, Lynda D. Prior ${ }^{12}$, Fidel Alejandro Roig ${ }^{65}$, Michael Ross ${ }^{66}$, Davi Rodrigo Rossatto ${ }^{67}$, Vivien Rossi $^{68}$, Lucy Rowland ${ }^{69}$, Ervan Rutishauser ${ }^{70}$, Hellen Santana ${ }^{26}$, Mark Schulze S1, Diogo Selhorst $^{72}$, Williamar Rodrigues Silva ${ }^{73}$, Marcos Silveira ${ }^{15}$, Susanne Spannl ${ }^{13}$, Michael D. Swaine ${ }^{74}$, José Julio Toledo ${ }^{75}$, Marcos Miranda Toledo $^{76}$, Marisol Toledo $^{77}$, Takeshi Toma ${ }^{78}$, Mario Tomazello Filho ${ }^{36}$, Juan Ignacio Valdez Hernández ${ }^{53}$, Jan Verbesselt ${ }^{14}$, Simone Aparecida Vieira ${ }^{79}$, Grégoire Vincent ${ }^{64}$, Carolina Volkmer de Castilho $^{80}$, Franziska Volland ${ }^{13}$, Martin Worbes ${ }^{81}$, Magda Lea Bolzan Zanon ${ }^{82}$, and Luiz E. O. C. Aragão ${ }^{1,83}$

${ }^{1}$ Remote Sensing Division, National Institute for Space Research - INPE, São José dos Campos 12227-010, SP, Brazil

${ }^{2}$ CIRAD, UMR Ecologie des Forêts de Guyane, Kourou 97379, France

${ }^{3}$ INRA, UMR EEF 1137, Champenoux 54280, France

${ }^{4}$ INRA, UMR Ecologie des Forêts de Guyane, Kourou 97387, France

${ }^{5}$ Department of Biology, University of Antwerp, Wilrijk 2610, Belgium

${ }^{6}$ National Center for Monitoring and Early Warning of Natural Disasters - CEMADEN,

São José dos Campos 12.247-016, SP, Brazil

${ }^{7}$ School of Geography, University of Leeds, Leeds LS2 9JT, UK

${ }^{8}$ Institute of Botany, University of Hohenheim, 70593 Stuttgart, Germany

${ }^{9}$ Laboratory for Wood Biology and Xylarium, Royal Museum for Central Africa, Tervuren 3080, Belgium

${ }^{10}$ Programa de Pós-graduação em Ciências de Florestas Tropicais, Instituto Nacional de Pesquisas da Amazônia,

Manaus 69067-375, AM, Brazil

${ }^{11}$ Embrapa Florestas, Brazilian Agricultural Research Corporation, Colombo 83411-000, PR, Brazil

${ }^{12}$ School of Biological Sciences, University of Tasmania, Hobart 7001, Tasmania, Australia

${ }^{13}$ Institute of Geography, University of Erlangen-Nuremberg, 91058 Erlangen, Germany

${ }^{14}$ Laboratory of Geo-information Science and Remote Sensing, Wageningen University,

Wageningen 6708PB, the Netherlands

${ }^{15}$ Centro de Ciências Biológicas e da Natureza, Laboratóio de Botânica e Ecologia Vegetal, Universidade Federal Do Acre, Rio Branco 69915-559, AC, Brazil

${ }^{16}$ Instituto Pirenaico de Ecologia, Consejo Superior de Investigaciones Cientificas (IPE-CSIC), Zaragoza 50059, Spain 
${ }^{17}$ Instituto Boliviano de Investigacion Forestal (IBIF), Santa Cruz de la Sierra 6204, Bolivia

${ }^{18}$ Centro de Energia Nuclear na Agricultura, Laboratóio de Ecologia Isotópica, Universidade de SÃo Paulo,

Piracicaba 13416903, SP, Brazil

${ }^{19}$ Departamento de Botânica, Universidade Federal do Paraná, Curitiba 81531-980, PR, Brazil

${ }^{20}$ Departamento de Botânica, Universidade Federal de Juiz de Fora (UFJF), Juiz de Fora 36015-260, MG, Brazil

${ }^{21}$ Programa de Pós-Graduação Ecologia e Manejo de Recursos Naturais, Universidade Federal do Acre,

Rio Branco 69915-559, AC, Brazil

${ }^{22}$ Departamento de Ecologia do Instituto de Biociências, Universidade de São Paulo (USP), São Paulo 05508-090, SP, Brazil

${ }^{23}$ UMR 5174 Laboratoire Evolution et DiversitéBiologique, CNRS \& UniversitéPaul Sabatier, Toulouse 31062, France

${ }^{24}$ Biological Sciences Department, University of Zambia, Lusaka Box 32379, Zambia

${ }^{25}$ Department of Biology, University of Missouri-St. Louis, Saint Louis 63121, MO, USA

${ }^{26}$ Coordenação de Pesquisas em Biodiversidade, Instituto Nacional de Pesquisas da Amazônia,

Manaus 69080-971, AM, Brazil

${ }^{27}$ Departamento de Engenharia Florestal, Universidade Federal de Viçosa (UFV), Viçosa 36570-000, MG, Brazil

${ }^{28}$ Departamento de Engenharia Florestal, Universidade Federal do Paraná, Curitiba 80210-170, PR, Brazil

${ }^{29}$ Centro de Ciêcias Biológicas e da Natureza, Laboratório de Botânica e Ecologia Vegetal, Universidade Federal do Acre,

Rio Branco 69915-559, AC, Brazil

${ }^{30}$ Prefeitura Municipal de Rio Branco, Rio Branco 69900-901, AC, Brazil

${ }^{31}$ Département Hommes, Natures, Sociétés, Centre National de la Recherche Scientifique (CNRS) et UMR 208 Patrimoines

Locaux et Gouvernance, Paris 75231 Cedex 05, France

${ }^{32}$ Dept. Forest and Wood Science, University of Stellenbosch, Stellenbosch 7600, South Africa

${ }^{33}$ Meisterschule Ebern für das Schreinerhandwerk, 96106 Ebern, Germany

${ }^{34}$ Floresta Estadual de Assis, Assis 19802-970, SP, Brazil

${ }^{35}$ Tanzania Forestry Research Institute (TAFORI), Dodoma P.O. Box 1576, Tanzania

${ }^{36}$ Departamento de Ciências Florestais, Universidade de São Paulo, Escola Superior de Agricultura Luiz de Queiroz,

Piracicaba 13418-900, SP, Brazil

${ }^{37}$ Departamento de Engenharia Florestal - DEF, Universidade Estadual do Centro-Oeste, Irati 84500-000, PR, Brazil

${ }^{38}$ Departamento de Ciências Florestais, Centro de Ciências Rurais, Universidade Federal de Santa Maria, Santa Maria 97105-9000, RS, Brazil

${ }^{39}$ Departamento de Botânica, Laboratório de Fisiologia Vegetal, Universidade de Brasília, Instituto de Ciências Biológicas, Brasília 70904-970, DF, Brazil

${ }^{40}$ World Agroforestry Centre (ICRAF), Nairobi P.O. Box 30677-00100, Kenya

${ }^{41}$ Coordenação de Pesquisa em Ecologia, Instituto Nacional de Pesquisas da Amazônia,

Manaus C.P. 478 69011-970, AM, Brazil

${ }^{42}$ Departement of Land Resource Management, Northern Territory Government, Palmerston NT 0831, Australia

${ }^{43}$ Research Institute for Environment and Livelihoods, Charles Darwin University, Darwin NT 0909, Australia

${ }^{44}$ Department of Biological Sciences, Mount Holyoke College, South Hadley 01075, MA, USA

${ }^{45}$ Department of Earth System Science, Stanford University, Stanford 94305, CA, USA

${ }^{46}$ Department of Natural Resources and Environmental Sciences, University of Illinois at Urbana Champaign, Champaign 61801, USA

${ }^{47}$ Department of Plant Ecology, Albrecht von Haller Institute of Plant Sciences, University of Göttingen, 37073 Göttingen, Germany

${ }^{48}$ Departamento de Engenharia Florestal, Universidade do Estado de Santa Catarina - UDESC, Lages 88520-000, SC, Brazil

${ }^{49}$ Tropical Peat Research Institute, Biological Research Division, Malaysian Palm Oil Board, Selangor 43000, Malaysia

${ }^{50}$ Departamento de Botânica, Instituto de Ciências Biologicas, Universidade Federal de Minas Gerais,

Belo Horizonte 31270-901, MG, Brazil

${ }^{51}$ Division of Science \& Environmental Policy, California State University Monterey Bay, Seaside 93955, CA, USA

${ }^{52}$ Departamento de Biologia, Universidade Federal de Sergipe, São Cristóvão 49100-000, Brazil

${ }^{53}$ Programa Forestal, Colegio de Postgraduados, Montecillo 56230, México

${ }^{54}$ Department of Geosciences and Geography, University of Helsinki, Helsinki 00014, Finland

${ }^{55}$ School of Geography and the Environment, University of Oxford, Oxford OX1 3QY, UK

${ }^{56}$ Departamento de Solos e Engenharia Agrícola, Universidade Federal do Paraná, Curitiba 80035-050, PR, Brazil

${ }^{57}$ Laboratoria de Dendrochronologia y Anatomia de Maderas Espinoza, Universidad Nacional de Loja,

Loja EC110103, Ecuador

${ }^{58}$ Tanzania Forestry Research Institute (TAFORI), Morogoro P.O. Box 1854, Tanzania 
${ }^{59}$ Research Institute for the Environment and Livelihoods, Charles Darwin University, Darwin NT 0909, Australia

${ }^{60}$ Center for Forest Disturbance Science, USDA Forest Service, Athens 30607, GA, USA

${ }^{61}$ Department of Biological Sciences, Florida International University, Miami 33199, FL, USA

${ }^{62}$ Graduate School of Agriculture, Kyoto University, Kyoto 606-8501, Japan

${ }^{63}$ Institut Français de Pondicherry, Puducherry 6005001, India

${ }^{64}$ UMR AMAP (botAnique et bioinforMatique de l'Architecture des Plantes), IRD, Montpellier 34398, France

${ }^{65}$ Tree Ring and Environmental History Laboratory, Instituto Argentino de Nivología, Glaciología y Ciencias Ambientales CONICET, Mendoza 5500, Argentina

${ }^{66}$ Department of Earth and Environment, Southeast Environmental Research Center, Florida International University, Miami 33199, FL, USA

${ }^{67}$ Departamento de Biologia Aplicada, FCAV, Universidade Estadual Paulista, UNESP, Jaboticabal 14884-000, SP, Brazil

${ }^{68}$ UR B\&SEF (Biens et services des écosystèmes forestiers tropicaux), CIRAD, Yaoundé BP 2572, Cameroon

${ }^{69}$ School of Geosciences, University of Edinburgh, Edinburgh EH9 3FF, UK

${ }^{70}$ CarboForExpert, Geneva 1211, Switzerland

${ }^{71} \mathrm{HJ}$ Andrews Experimental Forest, Oregon State University, Blue River 97413, OR, USA

${ }^{72}$ Ibama, Rio Branco 69907-150, AC, Brazil

${ }^{73}$ PRONAT - Programa de Pós-Graduação em Recurso Naturais, Universidade Federal de Roraima - UFRR, Boa Vista 69310-000, RR, Brazil

${ }^{74}$ School of Biological Sciences, University of Aberdeen, Aberdeen AB24 2TZ, UK

${ }^{75}$ Departamento de Ciências Ambientais, Universidade Federal do Amapá, Macapá 68902-280, AP, Brazil

${ }^{76}$ Embrapa Cocais, Brazilian Agricultural Research Corporation, São Luiz 65066-190, MA, Brazil

${ }^{77}$ Instituto Boliviano de Investigacion Forestal (IBIF), Universidad Autonoma Gabriel René Moreno, Santa Cruz de la Sierra CP 6201, Bolivia

${ }^{78}$ Department of Forest Vegetation, Forestry and Forest Products Research Institute (FFPRI), Ibaraki 305-8687, Japan

${ }^{79}$ Núcleo de Estudos e Pesquisas Ambientais (NEPAM), Universidade Estadual de Campinas (UNICAMP), Campinas 13083-867, SP, Brazil

${ }^{80}$ Embrapa Roraima, Brazilian Agricultural Research Corporation, Boa Vista 69301-970, RR, Brazil

${ }^{81}$ Crop Production Systems in the Tropics, Georg-August-University, 37077 Göttingen, Germany

${ }^{82}$ Departamento de Engenharia Florestal, Centro de Educação Superior Norte, Universidade Federal de Santa Maria, Frederico Westphalen 98400-000, RS, Brazil

${ }^{83}$ College of Life and Environmental Sciences, University of Exeter, Exeter EX4 4RJ, UK

Correspondence to: Fabien Hubert Wagner (wagner.h.fabien@gmail.com)

Received: 30 November 2015 - Published in Biogeosciences Discuss.: 18 January 2016

Revised: 14 April 2016 - Accepted: 15 April 2016 - Published: 28 April 2016

\begin{abstract}
The seasonal climate drivers of the carbon cycle in tropical forests remain poorly known, although these forests account for more carbon assimilation and storage than any other terrestrial ecosystem. Based on a unique combination of seasonal pan-tropical data sets from 89 experimental sites (68 include aboveground wood productivity measurements and 35 litter productivity measurements), their associated canopy photosynthetic capacity (enhanced vegetation index, EVI) and climate, we ask how carbon assimilation and aboveground allocation are related to climate seasonality in tropical forests and how they interact in the seasonal carbon cycle. We found that canopy photosynthetic capacity seasonality responds positively to precipitation when rainfall is $<2000 \mathrm{~mm} \mathrm{yr}^{-1}$ (water-limited forests) and to radiation otherwise (light-limited forests). On the other hand, independent of climate limitations, wood productivity and lit-
\end{abstract}

terfall are driven by seasonal variation in precipitation and evapotranspiration, respectively. Consequently, light-limited forests present an asynchronism between canopy photosynthetic capacity and wood productivity. First-order control by precipitation likely indicates a decrease in tropical forest productivity in a drier climate in water-limited forest, and in current light-limited forest with future rainfall $<2000 \mathrm{~mm} \mathrm{yr}^{-1}$.

\section{Introduction}

Tropical forests have a primary role in the terrestrial carbon (C) cycle. They constitute $54 \%$ of the total aboveground biomass carbon of Earth's forests (Liu et al., 2015) and account for half $\left(1.19 \pm 0.41 \mathrm{PgC} \mathrm{yr}^{-1}\right)$ of the global carbon sink of established forests (Pan et al., 2011; Baccini et al., 
2012). Based on annual or multi-annual measurements of forest wood productivity, changes in carbon dynamics and functioning of the tropical trees have already been observed. While tropical forests have been acting as a long-term, net carbon sink, a declining trend in carbon accumulation has been recently demonstrated for Amazonia (Brienen et al., 2015). Furthermore, a positive change in water-use efficiency of tropical trees due to the $\mathrm{CO}_{2}$ increase over the past 150 years has also been observed (van der Sleen et al., 2015; Bonal et al., 2011). Currently, increasing evidence shows that the tropical forests present a seasonality in the assimilation and storage of carbon, associated with climate seasonality (Wu et al., 2016; Doughty et al., 2014; Rowland et al., 2014b, a, 2015; Wagner et al., 2014). However, the inherent problem of these studies is that they are based on only one site or one region, which renders it difficult to disentangle the potential climate drivers due to collinearity between climate variables. Moreover, the studies sometime focus on a single part of the carbon cycle that may lead to erroneous interpretation on forest productivity due to interactions among the carbon cycle components (Doughty et al., 2014). Understanding the seasonal drivers of the carbon cycle in a pan-tropical context by using the maximum information available on carbon storage and assimilation is therefore needed to assess the mechanisms driving changes in forest carbon use and predict tropical forest behaviour under future climate changes.

Despite long-term investigation of changes in forest aboveground biomass stock and carbon fluxes, the direct effect of climate on the seasonal carbon cycle of tropical forests remains unclear. Contrasting results have been reported depending on methods used. Studies show an increase of aboveground biomass gain in the wet season from direct measurement (biological field measurements), or, from indirect measurement, an increase of canopy photosynthetic capacity in the dry season (remote sensing, flux tower network) (Wagner et al., 2013). Several hypotheses have been proposed to explain these patterns. (i) Wood productivity, estimated from trunk diameter increment, is mainly controlled by rainfall and water availability and occurs preferentially during the wet season, even if carbon accumulation in the trees could be greater in the dry season than in the wet season, likely reflecting a tradeoff between maximum potential growth rate and hydraulic safety (Rowland et al., 2014b, a; Wagner et al., 2014). Seasonal variation in carbon allocation to the different parts of the plant (crown, roots) also contributes to optimising resource use and could explain the low synchronicity between wood productivity and carbon accumulation in the trees (Doughty et al., 2014, 2015; Rowland et al., 2014b). (ii) Litterfall peaks mainly occur during dry periods in response to two potential climate drivers: seasonal changes in daily insolation leading to production of new leaves and synchronous abscission of old leaves, and high evaporative demand and low water availability, which both induce leaf shedding in the dry season (Borchert et al., 2015; Zhang et al., 2014; Wright and Cornejo, 1990; Chave et al., 2010;
Myneni et al., 2007; Jones et al., 2014; Bi et al., 2015); and (iii) Photosynthesis in these tropical forested regions is mainly limited by water and is sustained during the dry season above a threshold of $2000 \mathrm{~mm}$ of mean annual precipitation (Restrepo-Coupe et al., 2013; Guan et al., 2015). Water limitation is not the only known control, and other climate variables and internal carbon allocation have been demonstrated to drive photosynthetic capacity in tropical forests such as irradiance, temperature and leaf dynamics. Irradiance is directly and positively linked to plant photosynthetic capacity, carbon uptake and plant growth (Graham et al., 2003), while temperatures above $30^{\circ} \mathrm{C}$ drive a reduction of photosynthetic capacity (Lloyd and Farquhar, 2008; Doughty and Goulden, 2008; Doughty, 2011). Recently, for non-waterlimited forests in Amazonia, Wu et al. (2016) showed that the increase in ecosystem photosynthesis during dry periods result from the synchronisation of new leaf growth and litterfall, shifting canopy composition towards younger more light-use efficient leaves.

Here, we determine the dependence of seasonal aboveground wood productivity, litterfall and canopy photosynthetic capacity (using the MODIS enhanced vegetation index (EVI) as a proxy) on climate across the tropics, and assess their interconnections in the seasonal carbon cycle. EVI strongly correlated with chlorophyll content and photosynthetic activity (Huete et al., 2002, 2006), and we used a corrected version of the index to account for sun-angle artifact (Morton et al., 2014; Wagner et al., 2015). While positive correlation of leaf flushing and EVI has already been reported in tropical forests (Brando et al., 2010; Wagner et al., 2013; Wu et al., 2016), Chavana-Bryant et al. (2016) have demonstrated in a tropical forest that EVI increased with leaf development (from youngest to the most mature cohorts), and then declined when leaves were at old and senescent stages. Here we assume that EVI represents the maturation of new leaves and that the highest value of EVI represents the highest greenness and canopy photosynthetic capacity, when leaves are fully mature. We use a unique satellite and groundbased combination of monthly data sets from 89 pan-tropical experimental sites (68 include aboveground wood productivity and 35 litter productivity measurements), their associated canopy photosynthetic capacity and climate to address the following questions. (i) Are seasonal aboveground wood productivity, litterfall productivity and photosynthetic capacity all dependent on climate? (ii) Does a coherent pan-tropical rhythm exist among these three key components of forest carbon fluxes? (iii) If so, is this rhythm primarily controlled by exogenous (climate) or endogenous (ecosystem) processes? 


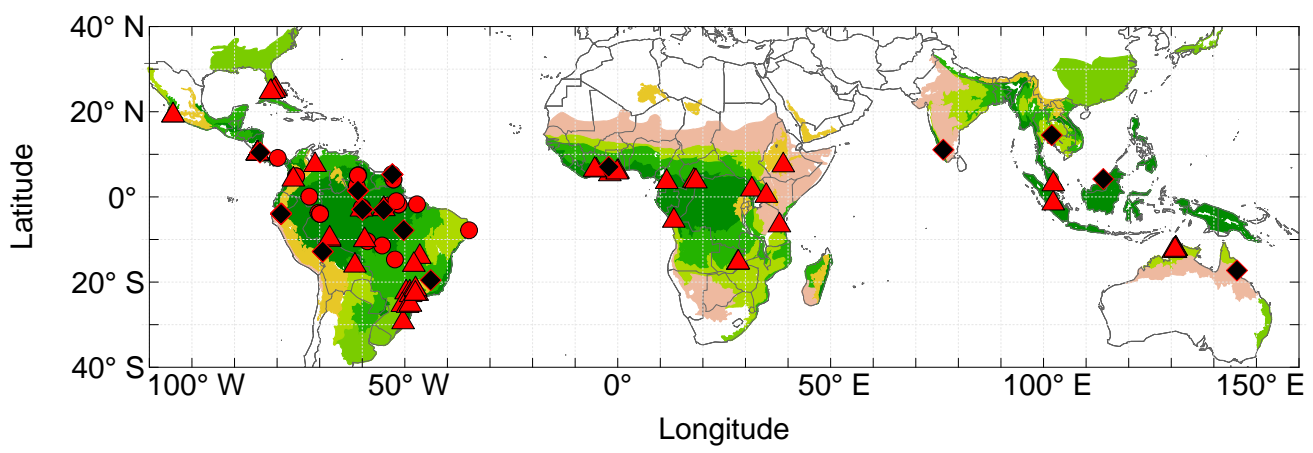

Global ecological zones

Field measurement types

Tropical rainforest

Tropical moist deciduous forest Subtropical humid forest

Tropical dry forest

Tropical mountain system

Tropical shrubland

Figure 1. Geographical locations of the 89 observation sites with the field measurement types (wood productivity and/or litter productivity) and global ecological zones (FAO, 2012). Wood productivity is available for 68 sites $(54+14)$, litter productivity for 35 sites $(21+14)$, and EVI and climate for all the 89 studied sites $(54+21+14)$.

\section{Methods}

\subsection{Data sets}

We compiled publications reporting seasonal wood productivity of tropical forests. Seasonal tree growth measurements in 68 pantropical forest sites, representing 14481 individuals, were obtained from published sources or directly from the authors (Table 1, Fig. 1). The data set consists of repeated seasonal measurements of tree diameter, mostly with dendrometer bands $(94.1 \%)$, electronic point surveys $(4.4 \%)$ or graduated tapes $(1.5 \%)$. The names of all recorded species were checked using the Taxonomic Name Resolution Service and corrected as necessary (Boyle et al., 2013; Chamberlain and Szocs, 2013). Botanical identifications were made at the species level for 11967 trees, at the genus level for 1613 trees, family level for 171 trees and unidentified for 730 trees. Wood density values were taken from the Global Wood Density Database (Chave et al., 2009; Zanne et al., 2009) or from the authors, when measured on the sample (Table 1). Direct determination was available for 455 trees and species mean was assumed for an additional 8671 trees. For the remaining 5355 trees, we assumed genus mean (4639), family mean (136) or site mean (580) of wood density values as computed from the global database (Zanne et al., 2009). Palms, lianas and species from mangrove environments were excluded from the analysis. Diameter changes were converted to biomass estimates using a tropical forest biomass allometric equation - which uses tree height (estimated in the allometric equation if not available), tree diameter and wood density (Chave et al., 2014) - and then the mean monthly incre- ment of the sample was computed for each sample. Recently, Cuny et al. (2015) showed that stem woody biomass production lags behind stem-girth increase by over 1 month in temperate coniferous forests, but here we assume that stemgirth increase represents woody biomass production as no such information is yet available for tropical forest trees. To detect the errors of overestimated or underestimated growth, the increment histogram of each site was plotted. For each suspected error, the increment trajectory of trees was then visually assessed to confirm the error. If the error was clearly identifiable, such as an abnormal increase (or decrease) in diameter values followed by a large decrease (or increase) of the same amplitude resulting from typographic errors, for example 28 whereas 2.8 was expected, the typographic error was corrected. When the typographic error was not clearly identifiable, the value was corrected with linear approximation with the mean increment of $t+1$ and $t-1$. In some cases there was an identifiable increase of diameter values (or decrease), but not followed by a decrease (or an increase) of the same amplitude. This pattern was associated to the repositioning of the dendrometer bands (reported in the source data set). In this case, the increment was deleted and set to zero and the new time series of cumulative diameter values were computed. As the diameter values are needed to compute biomass, this strategy was used to benefit of the full time series of diameter increment even after solving the error.

Seasonal litterfall productivity measurements from a previously published meta-analysis were used for South America (Chave et al., 2010) (description in Table 1 of Chave et al., 2010). In this data set, we used only monthly measurement 


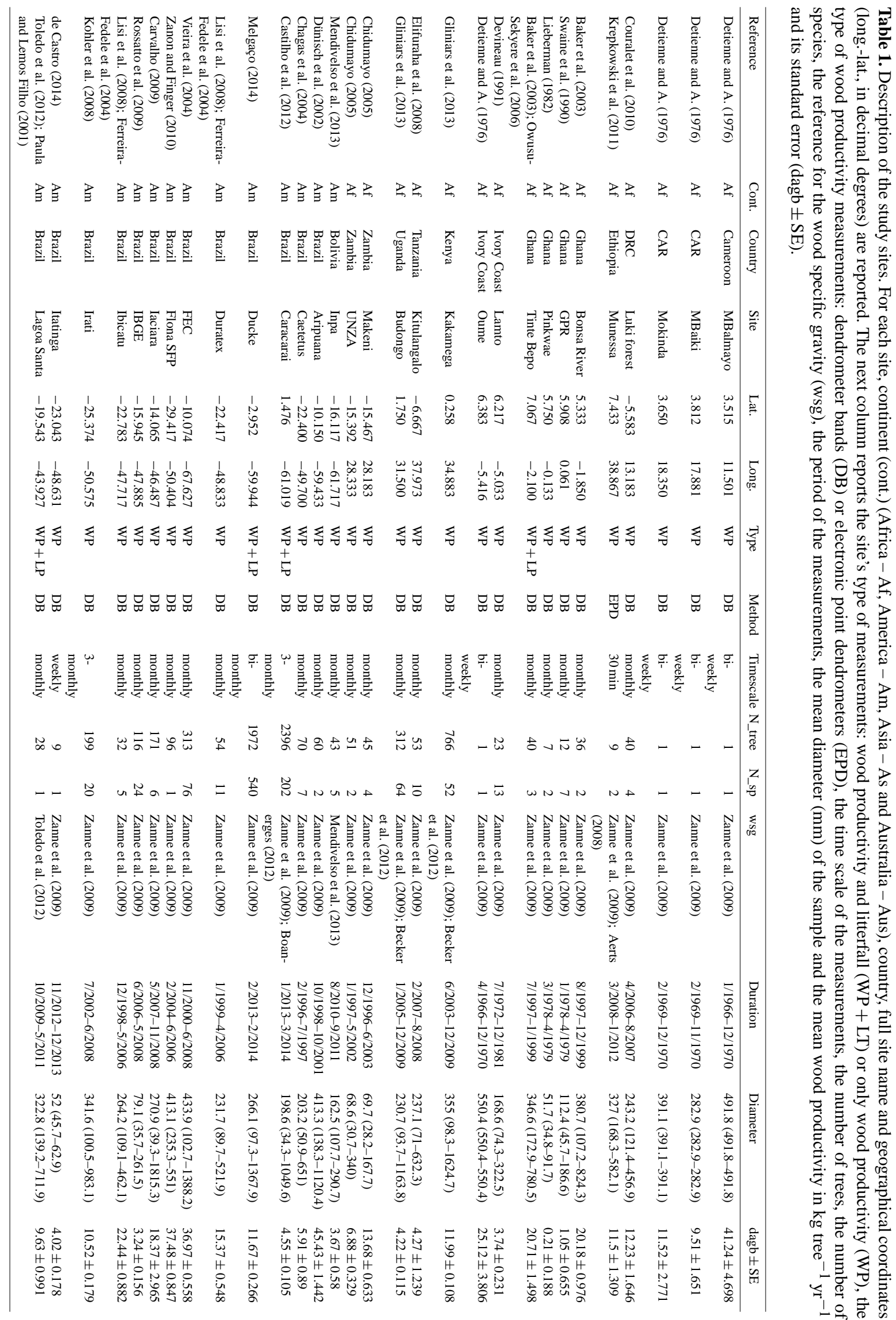




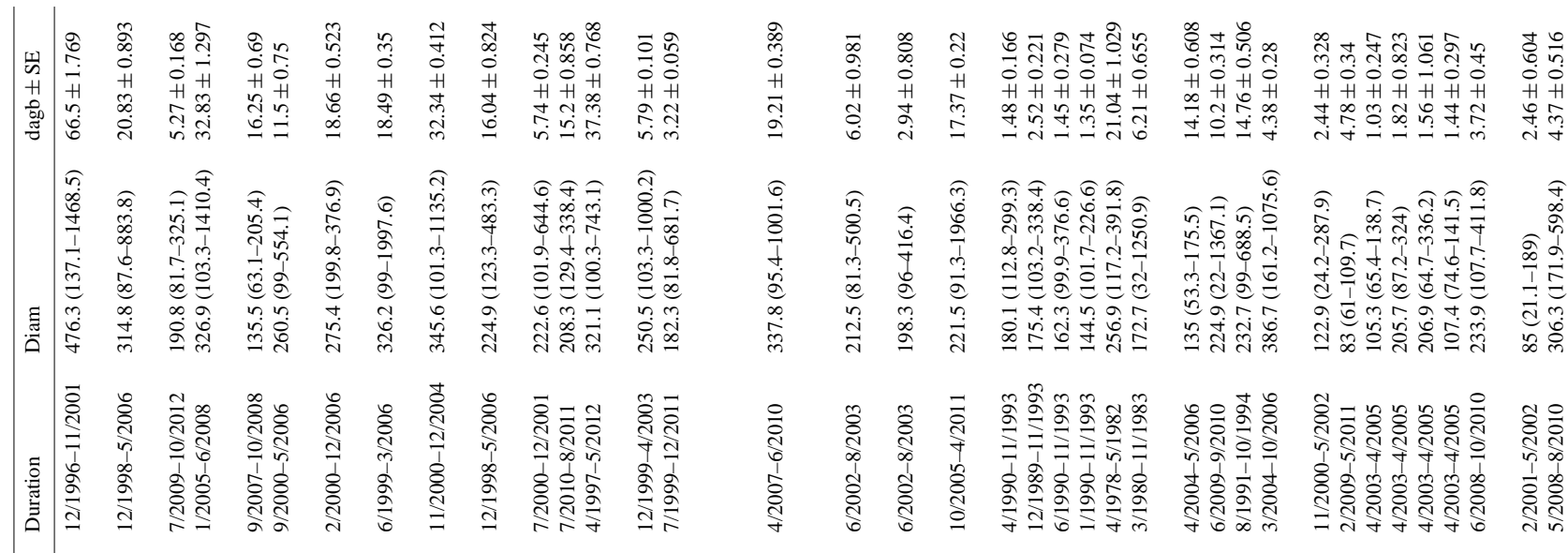

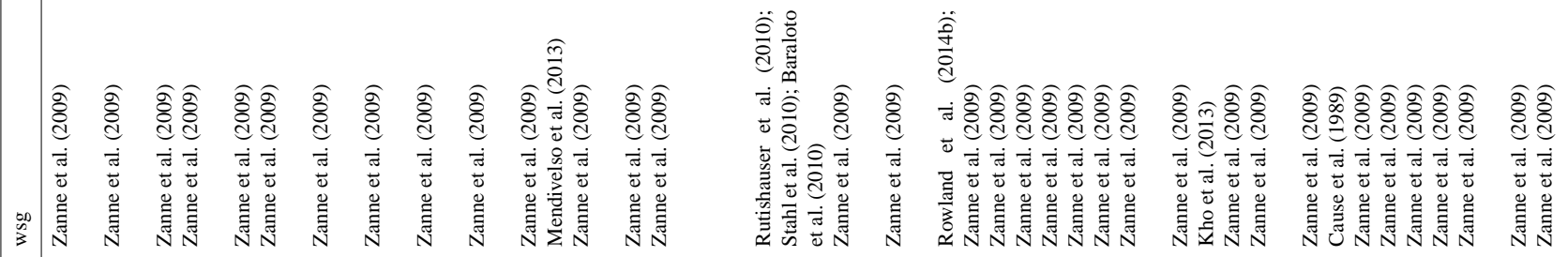

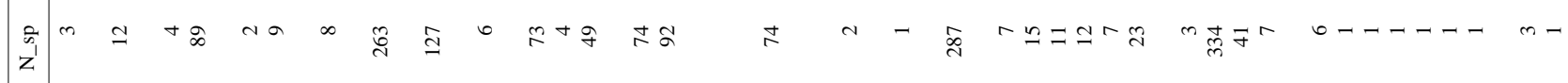
旅

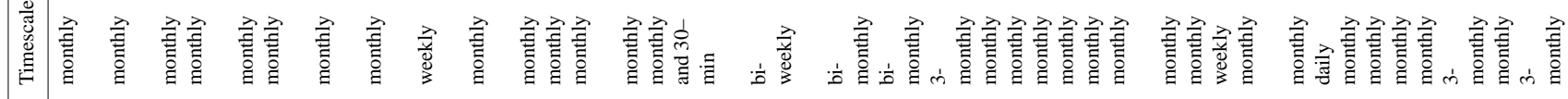
产

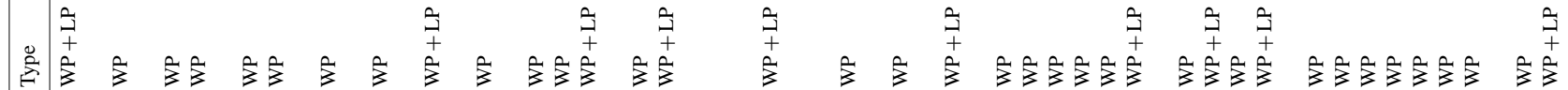
क人

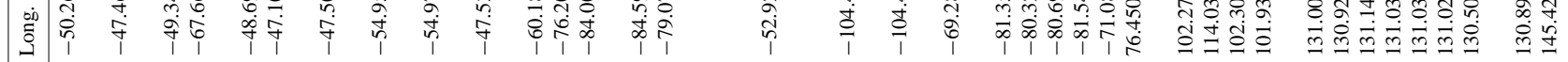

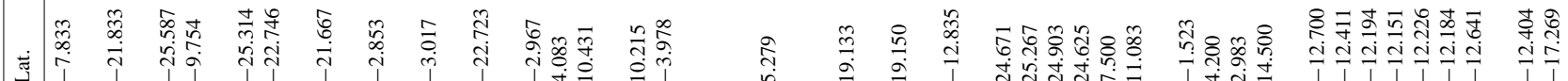

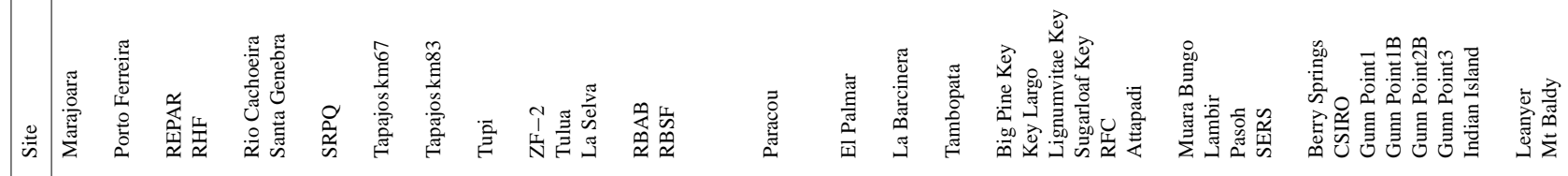

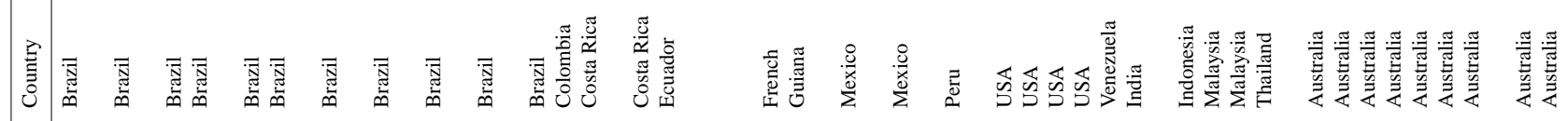

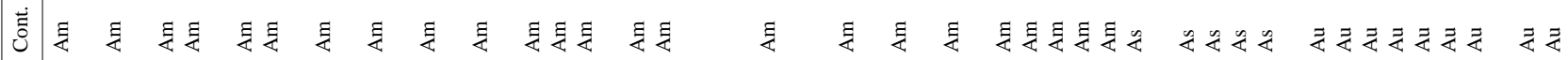

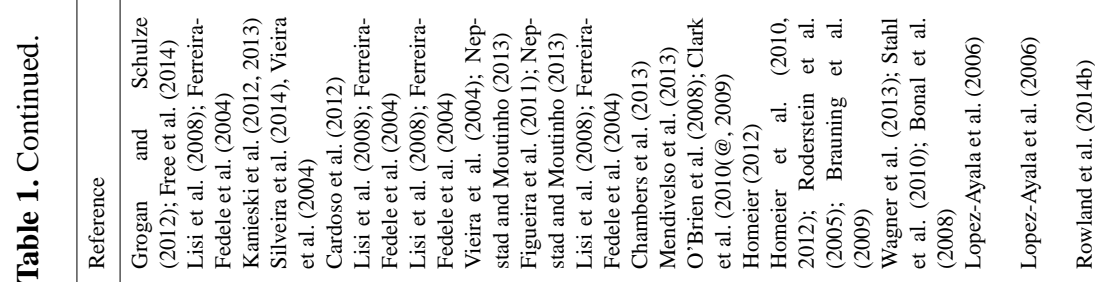

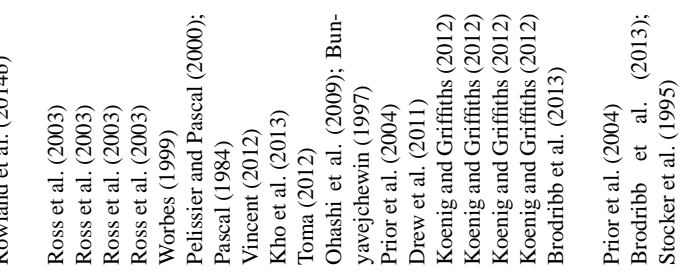


data from old-growth forests, as some sites have plots of both secondary and old-growth forests; flooded forests were excluded. In addition to these 23 sites, we compiled the seasonal leaf/litterfall data of 12 sites where we already had tree-growth measurements (Fig. 1 and Table 2). For these 35 sites, 26 had monthly leaf fall and 9 had monthly litterfall data (leaf fall, twigs usually less than $2 \mathrm{~cm}$ in diameter, flowers and fruits). The Pearson correlation coefficient between leaf fall and litterfall for the 20 sites where both data are available is 0.945 (Pearson test, $t=42.7597, \mathrm{~d} f=218, p$ value $<0.001)$. Consequently, we assumed that the seasonal pattern of litterfall is not different from the seasonal pattern of leaf fall.

Enhanced vegetation index (EVI) was used as a proxy for canopy photosynthetic capacity in tropical forest regions (Huete et al., 2006; Guan et al., 2015). EVI for the 89 experimental sites (Fig. 1) was obtained from the Moderate Resolution Imaging Spectroradiometer (MODIS) MCD43 product collection 5 provided every 16 days at $500 \mathrm{~m}$ spatial resolution (from 4 May 2002 to 30 September 2014). Before computing the mean monthly EVI per site, we did a pixel selection in five steps. (i) Selection of all the pixels in a square of side $40 \mathrm{~km}$, centred on the pixel containing each site $(6561$ pixels per site). This surface was selected to maximize the quantity of valid pixels to estimate monthly site's EVI, as, due to persistent cloud cover in tropical forest regions, valid observations of EVI are limited, producing incomplete time series of EVI values for a given pixel. (ii) In this area, the pixels containing the same or at least $90 \%$ of the site land cover pixel were selected, based on MCD12Q1 for 2001-2012 at $500 \mathrm{~m}$ resolution (Justice et al., 1998). (iii) Thereafter, only the pixels forested in 2000 and without loss of forest and with tree cover above or equal to the site tree cover were retained using global forest cover loss 2000-2012 and Data mask based on Landsat data (Hansen et al., 2013). (iv) Only pixels with a range of $\pm 200 \mathrm{~m}$ the site altitude were retained, using NASA Shuttle Radar Topographic Mission (SRTM) data, which were reprocessed to fill in the original no-data holes (Jarvis et al., 2008). (v) For corrected reflectance computation we used quality index from 0 (good quality) to 3 (all magnitude inversions or $50 \%$ or less fill-values) extracted from MCD43A2. When required, data sets used to make the selection were aggregated to the spatial resolution of MCD43 product $(500 \mathrm{~m})$ and reprojected in the MODIS sinusoidal projection. The reflectance factors of red $(0.620-0.670 \mu \mathrm{m}$,

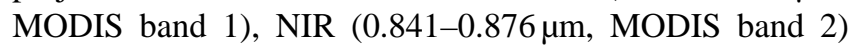
and blue bands (0.459-0.479 $\mu \mathrm{m}$, MODIS band 3$)$ of the retained pixels were modelled with the RossThick-LiSparseReciprocal model parameters contained in the MCD43A1 product with view angle $\theta_{\mathrm{v}}$ fixed at $0^{\circ}$, sun zenith angle $\theta_{\mathrm{s}}$ at $30^{\circ}$ and relative azimuth angle $\Phi$ at $0^{\circ}$ and EVI was computed as shown in Eq. (1):

$$
\mathrm{EVI}=2.5 \times \frac{\mathrm{NIR}-\text { red }}{\mathrm{NIR}+6 \times \text { red }-7.5 \times \text { blue }+1} .
$$

To filter the time series, EVI above or below the $95 \%$ confidence interval of the site's EVI values were excluded. Then, the 16-day time series were interpolated to a monthly time step. Finally, the interannual monthly mean of EVI for each site was computed. Further, the $\Delta \mathrm{EVI}_{\mathrm{wet}-\mathrm{dry}}$ index was computed for each site, that is, the differences of wet- and dryseason EVI normalized by the mean EVI, whereas dry season is defined as months with potential evapotranspiration above precipitation (Guan et al., 2015). For the sites where evapotranspiration is never above precipitation, dry season was defined as months with normalized potential evapotranspiration above normalized precipitation. In this study $\triangle \mathrm{EVI}_{\text {wet-dry }}$ computed from MODIS MCD43A1 is correlated with MOD13C1 (Amazonian sites: $\rho_{\text {Spearman }}=0.90$; pan-tropical sites: $\left.\rho_{\text {Spearman }}=0.86\right)$ and MAIAC (Amazonian sites: $\rho_{\text {Spearman }}=0.89$ ) products (Supplement Fig. S4).

To extract the monthly climate time series for the 89 experimental sites (Fig. 1), we used climate data sets from three sources: the Climate Research Unit (CRU) at the University of East Anglia (Mitchell and Jones, 2005), the Consortium for Spatial Information website (CGIAR-CSI, http: //www.cgiar-csi.org) and from NASA (Loeb et al., 2009). From the CRU, we used variables from the CRU-TS3.21 monthly climate global data set available at $0.5^{\circ}$ resolution from 1901 to 2012: cloud cover (cld, unit: \%); precipitation (pre, $\mathrm{mm}$ ); daily mean, minimal and maximal temperatures (respectively tmp, tmn and tmx, ${ }^{\circ} \mathrm{C}$ ); temperature amplitude $\left(\mathrm{dtr},{ }^{\circ} \mathrm{C}\right)$; vapour pressure (vap, $\mathrm{hPa}$ ); and potential evapotranspiration (pet, $\mathrm{mm}$ ). The maximum climatological water deficit (CWD) is computed with CRU data by summing the difference between monthly precipitation and monthly evapotranspiration only when this difference is negative (water deficit) (Chave et al., 2014). From the CGIAR-CSI, we used the Global High-Resolution Soil-Water Balance dataset, soil water content (swc, \%) (Zomer et al., 2008). Additionally, we used monthly incoming radiation at the top of the atmosphere (rad, $\mathrm{W} \mathrm{m}^{-2}$ ) covering the period from 2000 to 2015 at $1^{\circ}$ spatial resolution from the CERES instruments on the NASA Terra and Aqua satellites (Loeb et al., 2009) and monthly incoming radiation at the surface $\left(\operatorname{rad}_{\text {surf }}, \mathrm{W} \mathrm{m}^{-2}\right)$ from CERES SYN1deg product computed for all-sky conditions, provided at $1^{\circ}$ spatial resolution from 2000 to 2015 . Monthly incoming radiation at the surface (shortwave radiation) refers to radiant energy with wavelengths in the visible, near-ultraviolet, and near-infrared spectra and is produced using MODIS data and geostationary satellite cloud properties (Kato et al., 2011). In addition to the temporal series of climate variables, we extracted the global ecological zones (GEZs) of the sites. These GEZs are defined by the Food and Agriculture Organization of the United Nations (FAO) and relies on a combination of climate and (potential) vegetation (FAO, 2012).

Because at some sites wood productivity or litterfall measurements are older than the EVI measurements (before 2002), and, for recent site measurements, climate data are 


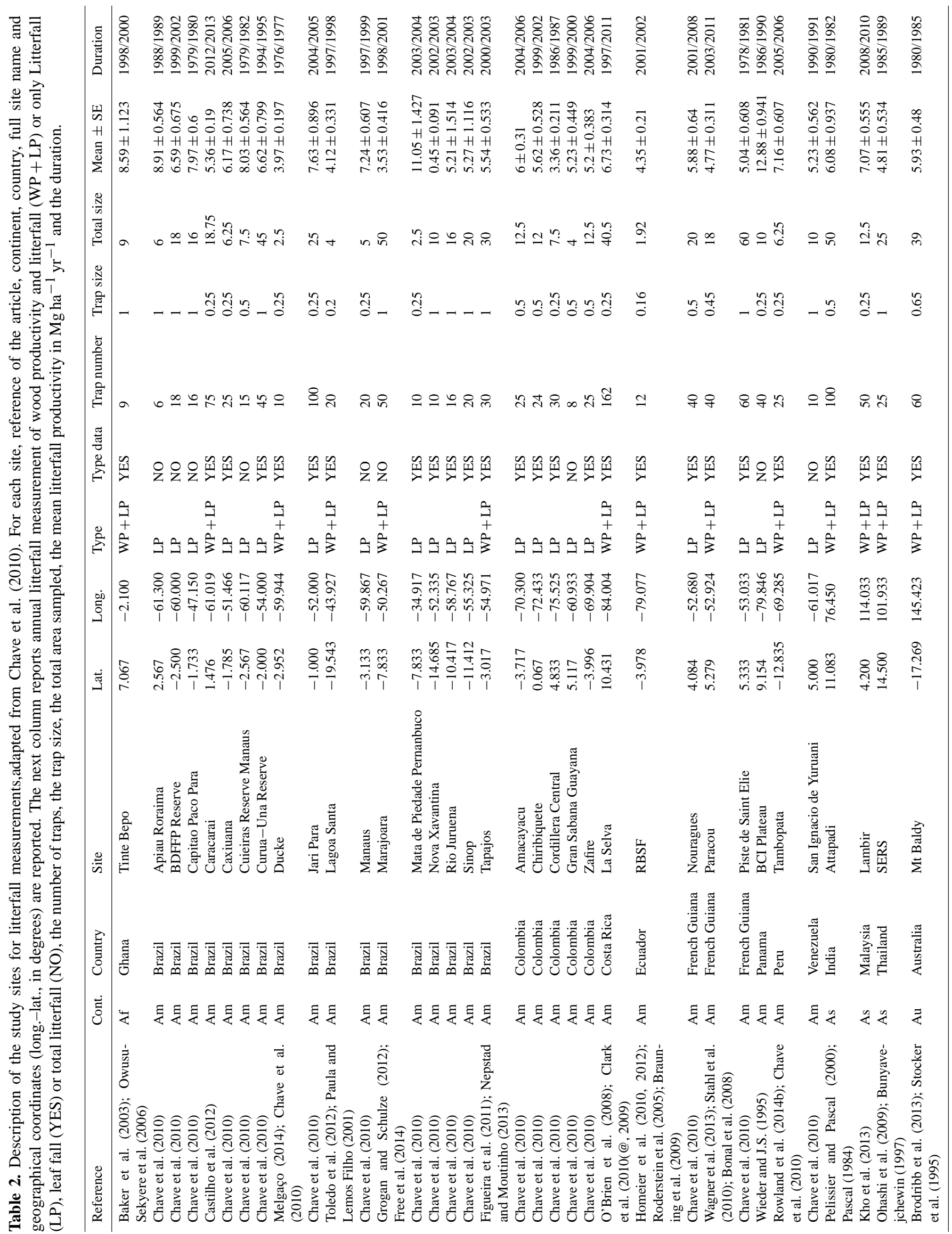


not yet available (after 2012), all the data sets were averaged monthly by site. Then, in order to remove the site effect on the mean and the variance of the variables and to analyse only seasonality, all the variables were centred on zero and scaled to a variance of 1 by site. That is, for a given variable of a site, monthly values were subtracted by their annual mean and divided by their annual standard deviation. The obtained normalized variable had a mean of 0 and a variance of 1 , but the time variation in the variable time-series, that is in our case the seasonality, remained completely unchanged.

The 89 sites represent a large sample of tropical forests under different tropical and subtropical climates corresponding to six global ecological tropical zones (FAO, 2012): tropical rain forest (TAr, 41 sites), tropical moist deciduous forest (TAwa, 23 sites), tropical dry forest (TAwb, 14 sites), tropical mountain systems (TM, 7 sites), tropical shrubland (TBSh, 1 site) and subtropical humid forest (SCf, 3 sites).

\subsection{Data analysis}

\subsection{Effect of stem hydration on wood productivity}

Changes in tree circumference measured with dendrometers are commonly used to characterise seasonal wood productivity. However, accelerated changes in circumference increments during the onset of the wet season can be caused by bark swelling as stems become hydrated (Stahl et al., 2010). Similarly, bark shrinking during dry periods can mask any secondary growth and even lead to negative growth increments (Stahl et al., 2010; Baker et al., 2002). Stem shrinkage during dry periods may be an important limitation of this work (Sheil, 2003; Stahl et al., 2010), as negative monthly growth values exist at almost all the study sites. Since the measurements are stem radius or circumference changes rather than wood formation, it is difficult to distinguish between true wood formation and hydrological swelling and shrinking. Direct measurements of cambial growth, such as pinning and micro-coring, currently represent the most reliable techniques for monitoring seasonal wood formation; however, all these methods are highly time-consuming, which severely restricts their applicability for collecting large data sets (Makinen et al., 2008; Trouet et al., 2012). Nevertheless, some observations already exist to compare growth from dendrometers and cambial growth at a seasonal scale for the same trees. In a tropical forest in Ethiopia experiencing a strong seasonality, high-resolution electronic dendrometers have been combined with wood anatomy investigation to describe cambial growth dynamics (Krepkowski et al., 2011). These authors concluded that water scarcity during the long dry season induced cambial dormancy (Krepkowski et al., 2011). Furthermore, after the onset of the rainy season, (i) bark swelling started synchronously among trees, (ii) bark swelling was maximum after few rainy days, and (iii) evergreen trees were able to quickly initiate wood formation. In a laboratory experiment of trunk section desiccation, Stahl et al. (2010) have shown a decrease in the diameter of the trunk sections ranging from 0.08 to $1.73 \%$ of the initial diameter. This decrease was significantly correlated with the difference in water content in the bark, but not with the difference in water content in sapwood. The variation in the diameter of the trunk sections were observed when manipulating the chamber relative air humidity from 90 to $40 \%$. However, these values are not representative of the in situ French Guiana climatic conditions, which is where the trunk sections have been collected and where relative humidity never falls below $70 \%$. Negative increments were reported for onequarter of their sample with dendrometers measurements in the field. Recently, at the same site, some authors showed that biomass increments were highly correlated between the first and last quantiles of trunk bark thickness and between the first and the last quantile of trunk bark density, thereby suggesting that secondary growth is driven by cambial activity (Wagner et al., 2013) and not by water content in bark. At Paracou, a recent study showed a decrease or stop in the cambial growth for some species during the dry season, based on analysis of tree rings (Morel et al., 2015).

In a temperate forest, Makinen et al. (2008) simultaneously using dendrometer pinning and micro-coring on Norway spruce and Scots pine, Makinen et al. (see Figs. 3 and 5 in 2008) showed that a lag of 2 weeks exists between the growth measured by dendrometers, but the general pattern of growth is highly correlated. In La Selva (Costa Rica), where there is no month with precipitation below $100 \mathrm{~mm}$, a seasonal variation is reported, thereby suggesting a seasonality only driven by cambial growth. In conclusion, swelling and shrinking exist and could result from different biotic and abiotic causes, cell size, diameter, bark thickness and relative air humidity (Stahl et al., 2010; Baker et al., 2002). To test how swelling and shrinking affect our results, we made first a linear model of wood productivity with precipitation as a single predictor with all the data, and then a similar linear model discarding the first month of the wet season (first month with precipitation $>100 \mathrm{~mm}$ ) and the first month of the dry season (precipitation $<100 \mathrm{~mm}$ ). Here, we assume that swelling occurs in the first month of the wet season and shrinking occurs in the first month of the dry season, as already observed. The removal of the first month of dry and wet seasons (defined, respectively, as the first month with precipitation $>100 \mathrm{~mm}$ and the first month with precipitation $<100 \mathrm{~mm}$ ) did not affect the results of the linear model of wood productivity as a function of precipitation, that is, intercepts and slopes are not significantly different in both models (overlaps of the $95 \%$ confidence interval of coefficients and parameters, Table 3).

\subsection{Seasonality analysis}

To address the first question "Are seasonal aboveground wood productivity, litterfall productivity and photosynthetic capacity dependent on climate?", we analysed with linear models the relationship between our variable of interest 
Table 3. Coefficient of the linear model of wood productivity with the precipitation; with all data $m_{\mathrm{WP}}$ or after removing the first month of the dry season and wet season (defined, respectively, as the first month with precipitation $>100 \mathrm{~mm}$ and the first month with precipitation $<100 \mathrm{~mm}), m_{\mathrm{WP}, \text {-init }}$.

\begin{tabular}{rrrrrrr}
\hline Model & Parameter & Value & $2.5 \% \mathrm{CI}^{*}$ & $97.5 \% \mathrm{CI}^{*}$ & $p$ value & $R^{2}$ \\
\hline \multirow{2}{*}{$m_{\mathrm{WP}}$} & (Intercept) & -0.001 & -0.05 & 0.05 & 0.982 & 0.433 \\
& precipitation & 0.66 & 0.64 & 0.74 & $<0.0001$ & \\
\multirow{2}{*}{$m_{\text {WP, -init }}$} & (Intercept) & -0.03 & -0.08 & 0.02 & 0.284 & 0.466 \\
& precipitation & 0.67 & 0.61 & 0.72 & $<0.0001$ & \\
\hline
\end{tabular}

*: confidence intervals of the model parameters.

(wood productivity, litterfall productivity and photosynthetic capacity) and each climate variable at each site and at $t, t-1$ month and $t+1$ month. These lags were chosen to account for variations between years in the climate seasonality, as we used in our analysis the average climate per site. For example, if the tree diameter increments were measured during a year with a wet-season initiation delayed by 1 month in relation to the average year, a lag of 1 month could exist in the relation of the tree diameter increments and the monthly averages of precipitation used in linear models. The results were classified for each variable as a count of sites with significantly positive, negative or non-significant results. To enable between-sites comparison, when the overall link was negative, the linear model was then run with the climate variable multiplied by -1 . For a given climate variable, a site with a significant association at only one of the time lags $(-1,0$ or 1) was classified as significant. This strategy enables us to highlight the potential drivers of our variable of interest, which are the climate variables with a constant relation with the variable of interest in all the sites. Climate variable with no effect, or effect due to a particular correlation with a potential driver at some sites, will show changes in the sign of the relation with the variable of interest. Then, a McNemar test was run to compare the proportion of our classification (negative, positive or no relationship) between all paired combinations of climate variables accounting for dependence in the data, that is, to compare not only the proportion of positive, negative and no significant effect between two climate variables and the variable of interest but also to detect if the sites in each of the classes (positive, negative and no significant effect) were similar. In order to summarise all the relations between the climate variables, a table (similar to a correlation table) containing all paired combination $p$ values of the McNemar test was built. In this table a $p$ value $<0.05$ indicate that a different association between the two climate variables and the variables of interest cannot be rejected. To determine which climate variables explain the same part of variance and to enable interpretation, a cluster analysis was performed on the table of $p$ values of the McNemar test using Ward distance. Climate variables in the same cluster indicate that they share a similar relation with the variable of interest.
When the climate variable with direct effect was identified, we built a linear model to predict wood and litter productivity seasonality with climate in all sites. For EVI, two climate variables were identified and their influence was dependent

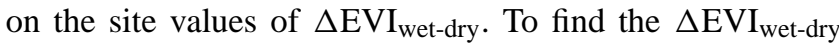
threshold of main influence of each variable, the $R^{2}$ of the linear relationship EVI as a function of the climate variable for different values of $\Delta \mathrm{EVI}_{\text {wet-dry }}$ threshold were computed. $R^{2}$ was computed for the sample above or below $\Delta \mathrm{EVI}_{\text {wet-dry }}$ depending on the relationship of each variable to the threshold. The optimal threshold of $\Delta \mathrm{EVI}_{\text {wet-dry }}$ for climate variable influence on normalized EVI was defined by a break in the decrease of $R^{2}$ values. Optimal thresholds were then used to define the range of $\Delta \mathrm{EVI}_{\mathrm{wet}}$-dry where $\mathrm{EVI}$ is influenced by one of the climate variables, the other and by both. To find the best linear combination of variables that contains the maximum information to predict EVI, we ran an exhaustive screening of the candidate models with the identified climate variables and their interactions with the $\Delta \mathrm{EVI}_{\mathrm{wet}-\mathrm{dry}}$ classes using a stepwise procedure based on the Bayesian information criterion, BIC (Schwarz, 1978).

To address the second question "Does a coherent pantropical rhythm exist among these three key components of the forest carbon fluxes?", we analysed the linear relationship between wood, litter productivity and canopy photosynthetic capacity. The non-parametric Mann-Whitney test was used to determine the association between wood/litter productivity and photosynthesis rhythmicity depending on site limitations.

To address the third question - is the rhythm among these three key components of the forest carbon controlled by exogenous (climate) or endogenous (ecosystem) processes? we analysed the linear relationship between $\Delta \mathrm{EVI}_{\text {wet-dry }}$ and mean annual precipitation, as well as the relationship between $\Delta \mathrm{EVI}_{\text {wet-dry }}, \Delta$ wood productivity $_{\text {wet-dry }}$ and $\Delta$ litter productivity ${ }_{\text {wet-dry }}$ and maximum climatological water deficit (CWD). $\Delta \mathrm{EVI}_{\text {wet-dry }}, \Delta$ wood productivity wet-dry $_{\text {and }} \Delta$ litter productivity $_{\text {wet-dry }}$ indices are the differences of wet- and dry-season variable values normalized by the mean of the variable, where the dry season is defined as months with potential evapotranspiration above precipitation. 
To avoid over-representation of sites with the "same climate" (that is, to account for spatial and temporal autocorrelation in the climate data) cross correlation (positive and negative) were computed within sites for the monthly climate variables rad, pre, pet, dtr, tmn and tmx. The site's annual values of the same climate variables were added in the table. After scaling and centring the table, the Euclidian distance between each site and the mean table of all other sites (barycentre) was computed. We defined the weight of each site as the distance to the other divided by the maximum distance to the other. This distance was used as a weight in the linear models.

All analysis were performed in $R$ (Team, 2014).

\section{Results}

\subsection{Climate footprint in seasonal carbon assimilation and storage}

A direct and dominant signal of precipitation seasonality was found in seasonality of wood productivity for 59 out of the 68 sites $(86.8 \%)$ where wood productivity data were available (cluster of variables in Fig. 2a with temperature amplitude (dtr), cloud cover (cld), precipitation (pre) and soil water content (swc), Sect. 2.2 and Supplement Table S1). All the variables in this cluster are wet season indicators: low temperature amplitude, high precipitation, high soil water content and high cloud cover. Two other clusters of climate variables are apparently associated with wood productivity. However, the climate variables that better explained wood productivity in these two clusters, vapour pressure (vap) and mean temperature (tmp), respectively, are highly correlated with precipitation in the clusters (Fig. 2a and Tables S3-S4). In spite of this dominant signal, these are outliers in our data, that exhibit no relationship or a negative relationship with precipitation (Appendix A1). Four of the five sites that have no dry season (months with precipitation below $100 \mathrm{~mm}$ ) were amongst these outliers.

It is interesting to note that $48.0 \%$ of the monthly wood productivity is explained by the single variable "precipitation" (model $m_{\mathrm{WP}}$ in Table 4). The linear model with monthly precipitation only ( $m_{\mathrm{WP}}$ ) was able to reproduce the seasonality of the majority of the sites analysed (Fig. 3a). No monthly lag between predicted and observed seasonality was observed for 35 sites. For 63 sites, a lag between -2 and +2 months was observed (Fig. 4a).

Canopy photosynthetic capacity, as estimated by EVI, for the 89 experimental sites, displayed an intriguing pattern with monthly precipitation, apparently related to the difference of $\Delta E V I_{\text {wet-dry }}$ (Fig. 5a), an indicator of the dry season evergreen state maintenance (Guan et al., 2015), computed as the difference between the mean EVI of the wet season $\left(p_{\text {re }} \geq\right.$ pet $)$ and of the dry season $\left(p_{\text {re }}<\right.$ pet $)($ Sect. 2.1). This pattern can be explained by a change in the climate pa-
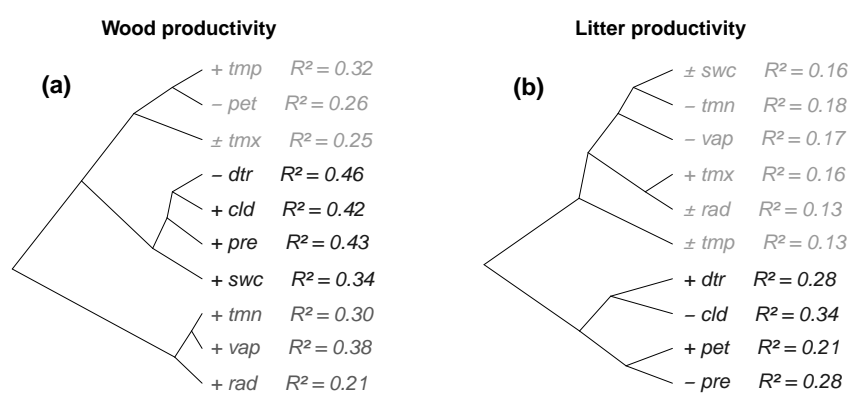

Figure 2. Dendrogram of the climate seasonality associations with the seasonality of wood productivity (a) and litterfall (b). The global sign and $R^{2}$ of the linear relationship between wood and litter productivity and the following climate variable is given. + indicates a positive correlation between the climate variable and wood or litter productivity in all the sites, - a negative correlation in all the sites, while \pm indicates positive correlation for a portion of the sites while negative for the other. Climate variables in the same cluster are highly correlated, that is, they produce the same prediction in terms of values and effects for the same sites. Different shades of grey indicate the relative strength of associations for each cluster with seasonality of wood or litter productivity, black indicates the strongest association. cld: cloud cover; pre: precipitation; rad: solar radiation at the top of the atmosphere; tmp, tmn and tmx are respectively the daily mean, minimal and maximal temperatures; dtr: temperature amplitude; vap: vapour pressure; pet: potential evapotranspiration; and swc: relative soil water content.

rameters that mainly control photosynthesis, from precipitation in water-limited sites $\left(\Delta \mathrm{EVI}_{\text {wet-dry }}>0.0378\right.$, Fig. $\left.5 \mathrm{~b}\right)$ to maximal temperature in light-limited site $\left(\Delta \mathrm{EVI}_{\text {wet-dry }}<\right.$ -0.0014 , Figs. 5c and S1). Sites with mixed influence of precipitation and temperature are found between the range of $\Delta \mathrm{EVI}_{\mathrm{wet}-\text { dry }}[-0.0014 ; 0.0378]$ (Fig. 6 for the definition of the thresholds). In our sample, the shift in climate control depends on the annual water availability. That is, sites are not water-limited above $2000 \mathrm{~mm} \mathrm{yr}^{-1}$ of mean annual precipitation (Fig. 5d), as previously observed (Guan et al., 2015). Rather, they are light-limited as shown by the relationship between photosynthetic capacity and maximal temperature (Fig. 5c). Light-limited sites are located in Amazonia, in the south of Brazil and in south-east Asia (Fig. 7). For all the sites, maximal temperature is highly correlated with incoming solar radiation at the surface $\left(r_{\text {Pearson }}=0.80\right.$, $p<0.0001$ ), approximating solar energy available for the plants (Fig. 8). With the model $\mathrm{mBIC}_{\mathrm{EVI}}$ (Table 4), precipitation, maximal temperatures and their thresholds explained $54.8 \%$ of the seasonality of photosynthetic capacity (Fig. 3c). For 39 sites, no seasonal lag between predicted and observed seasonality of canopy photosynthetic capacity was observed using the model $\mathrm{mBIC}_{\mathrm{EVI}}$. However, a majority of the sites ( 82 sites) appeared to have a lag between -2 and +2 months (Fig. 4c). The model failed to reproduce the seasonality for seven sites (one water-limited, one light-limited and five mixed sites). 
Table 4. Intercepts and slopes of the fitted linear models for seasonal wood production $\left(m_{\mathrm{WP}}\right)$, litterfall $\left(m_{\mathrm{lit}}\right)$ and EVI (mBIC $\left.\mathrm{EVI}\right)$; with the seasonal climate variables: precipitation (pre), cloud cover (cld) and maximal temperature (tmx). Light-, water- and mixed limitation indicate the limitation of the sites and are defined with the value of $\Delta \mathrm{EVI}_{\mathrm{wet} \text {-dry }}$ (Fig. 6 for the definition of the thresholds).

\begin{tabular}{lcrrrr}
\hline Model & Components & Coefficien (std. error) & t value & $p$ value & $R^{2}$ \\
\hline Wood production $\left(m_{\mathrm{WP}}\right)$ & Intercept & $0.0005(0.0249)$ & 0.02 & 0.9833 & 0.480 \\
\cline { 2 - 5 } & Precipitation & $0.6869(0.0260)$ & 26.40 & $<0.0001$ \\
\hline \multirow{2}{*}{ Litterfall $\left(m_{\text {lit }}\right)$} & Intercept & $0.0000(0.0389)$ & 0.00 & 0.9999 & 0.317 \\
\cline { 2 - 4 } & Cloud cover & $-0.5685(0.0407)$ & -13.98 & $<0.0001$ \\
\hline \multirow{2}{*}{ EVI $\left(\mathrm{mBIC}_{\mathrm{EVI}}\right)$} & $\begin{array}{c}\text { Intercept } \\
\text { Maximal temperature } \\
\text { in light-limited sites }\end{array}$ & $0.0000(0.0197)$ & 0.00 & 0.9999 \\
\cline { 2 - 4 } & $\begin{array}{c}\text { Maximal temperature } \\
\text { in sites with mixed limitations }\end{array}$ & $0.1683(0.0545)$ & 3.09 & 0.0020 & 0.548 \\
\cline { 2 - 4 } & $\begin{array}{c}\text { Maximal temperature } \\
\text { in water-limited sites }\end{array}$ & $-0.1100(0.0275)$ & -4.00 & $<0.0001$ \\
\cline { 2 - 4 } & $\begin{array}{c}\text { Precipitation } \\
\text { in sites with mixed limitation }\end{array}$ & $0.3697(0.0545)$ & 6.78 & $<0.0001$ \\
\cline { 2 - 4 } $\begin{array}{c}\text { Precipitation } \\
\text { in water-limited sites }\end{array}$ & $0.8149(0.0275)$ & 29.60 & $<0.0001$ \\
\hline
\end{tabular}
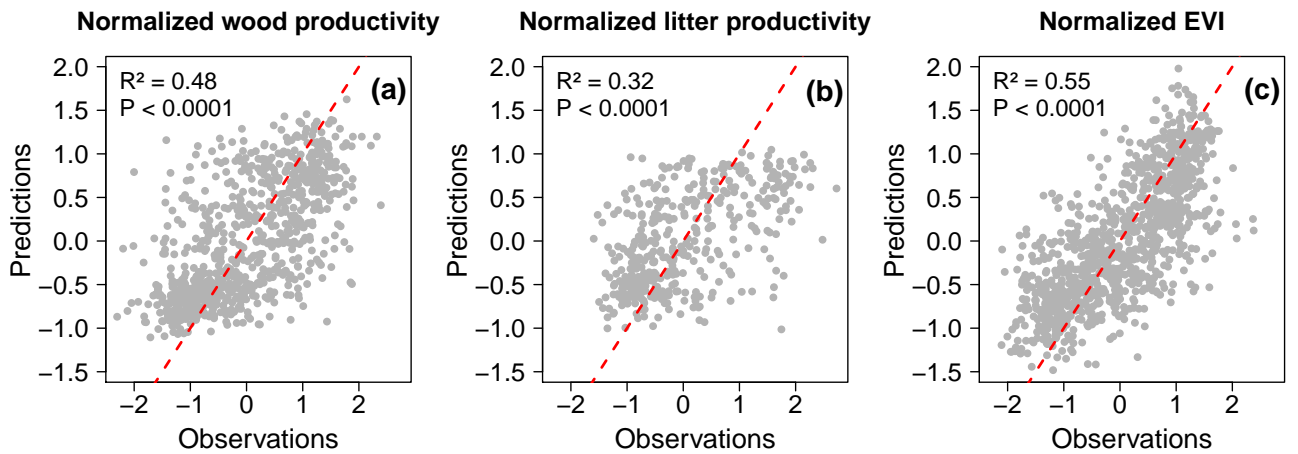

Figure 3. Observed vs. predicted monthly wood productivity under the model only with precipitation, $m_{\mathrm{WP}}$ (a); litterfall productivity under the model only with cloud cover, $m_{\text {lit }}(\mathbf{b})$; and EVI the model only with precipitation, maximal temperature and site limitations, $\mathrm{mBIC}_{\mathrm{EVI}}$ (c). The red dashed line is the identity line $y=x$. Parameters of the models are given in Table 4 .

For 27 out of the 35 sites $(77.1 \%)$ where litter data were available, litter productivity was associated with dry season indicators (lack of precipitation, high evaporation, low soil water content and high temperature amplitude, Fig. 2b). Surprisingly, we found that cloud cover (cld), an indirect variable, was the best single predictor of litterfall seasonality (Table 4). Direct effects are observed only for potential evapotranspiration (pet) and temperature amplitude (dtr) (Fig. 2b and Table S5). A second cluster of climate variables is associated with litter productivity but a key variable in this subgroup, minimal temperature (tmn), is correlated with cloud cover (cld) (Table S7). Despite this dominant signal, outliers showing no relationship with cld exist in our data (Ap- pendix A2). The predictive model with cloud cover as a single variable (Table 4) explains $31.7 \%$ of the variability and performs well to reproduce the seasonality of litterfall productivity (Figs. $3 b$ and $4 b$ ).

At a pan-tropical scale, $48 \%$ of the variability of monthly aboveground wood productivity (Fig. 3a and Table 4) and $31.7 \%$ of the monthly litterfall seasonality can be linearly explained with a single climate variable (Fig. 3b). The relationship between photosynthetic capacity (EVI) and climate is more complex; however, $54.8 \%$ of the monthly EVI variability can be linearly explained with only two climate variables, precipitation and maximal temperature (Fig. 3c). 

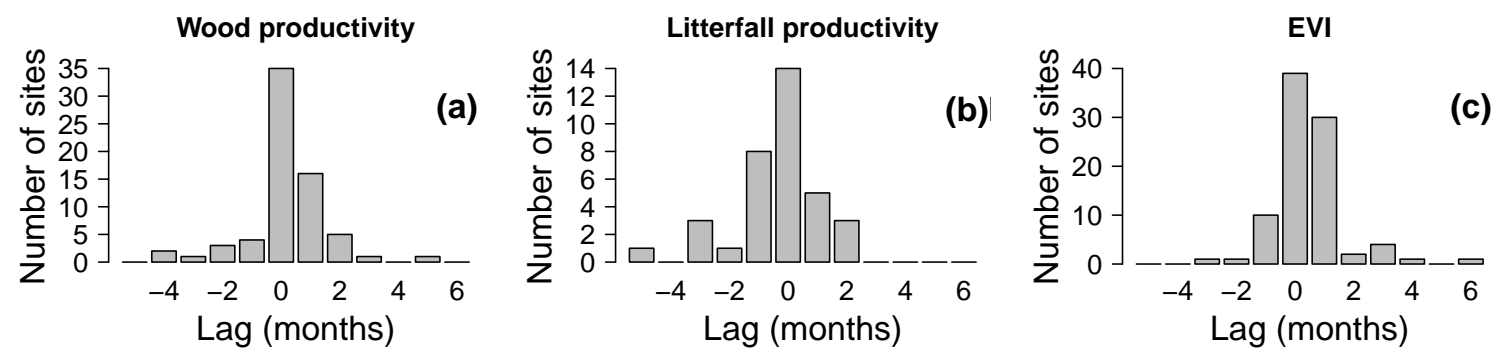

Figure 4. Cross correlation between observations and predictions of wood production (a), litterfall (b) and EVI (c) with the linear models parameters (Table 4). A cross correlation of zero month indicates a similar seasonal pattern in the time series of observations and predictions.
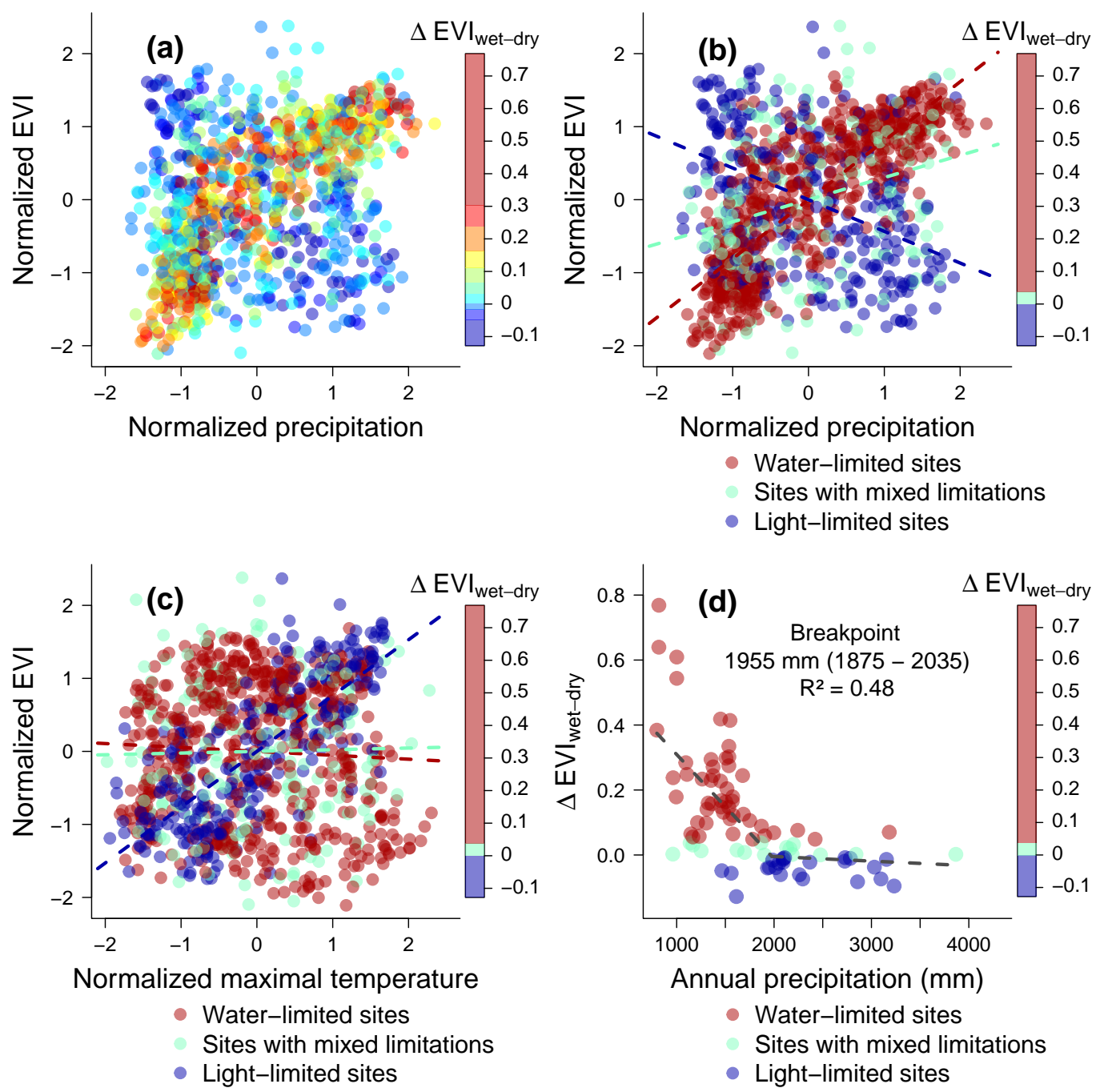

Figure 5. Monthly associations of EVI with precipitation (a, b), maximal temperatures (c), and association of $\Delta \mathrm{EVI}_{\mathrm{wet}-\mathrm{dry}}$ with mean annual precipitation (d). In (a) colours represent the value of $\Delta \mathrm{EVI}_{\mathrm{wet}}$-dry while in (b), (c) and (d) colours represent $\Delta \mathrm{EVI}_{\mathrm{wet}}$-dry grouped by the following classes : water-limited sites $\left(\Delta \mathrm{EVI}_{\mathrm{wet}-\mathrm{dry}}>0.0378\right)$, sites with mixed limitations $\left(\Delta \mathrm{EVI} \mathrm{I}_{\mathrm{wet}-\mathrm{dry}}[-0.0014 ; 0.0378]\right)$ and light-limited sites $\left(\triangle \mathrm{EVI}_{\text {wet-dry }}<-0.0014\right)$. The dashed lines in (b) and (c) represent the linear relationship between climate variable and observed EVI for water-limited sites, sites with mixed limitations and light-limited sites. Parameters of the models are given in Table S8. The dashed lines in (d) represents the best regression model with a breakpoint between $\Delta \mathrm{EVI}_{\mathrm{wet} \text {-dry }}$ and mean annual precipitation. 

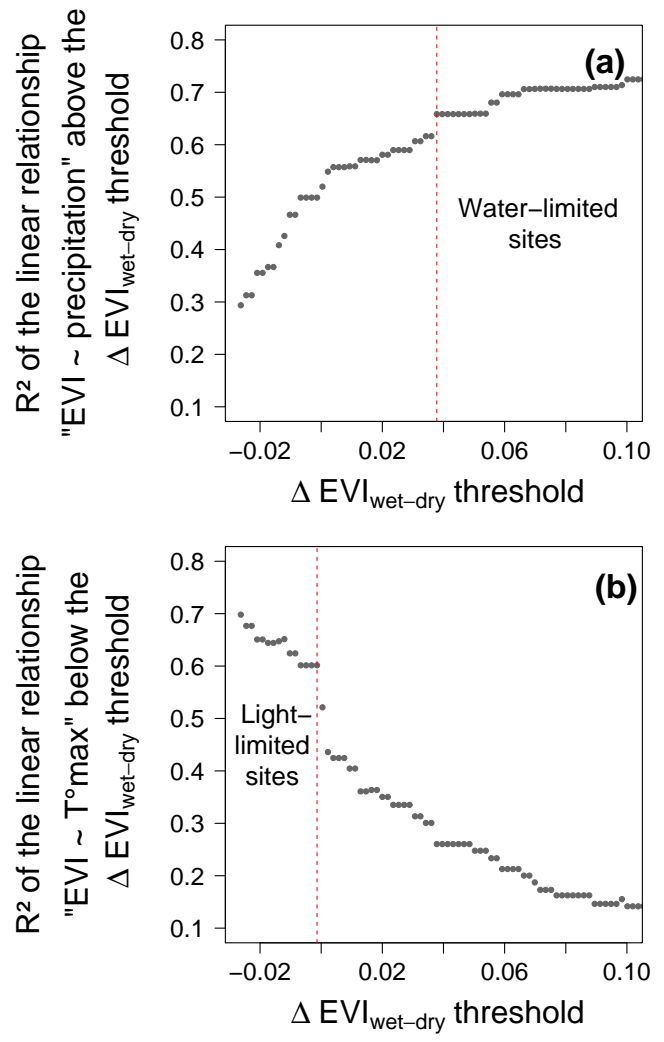

Figure 6. Threshold of $\Delta E V I_{\text {wet-dry }}$ used to define "water-limited" sites (a) and "light-limited" sites (b). Sites with $\Delta \mathrm{EVI}_{\mathrm{wet}}$-dry between the two thresholds had a mixed influence of the two climate variables and were qualified as "mixed". The names of the classes represent the main climate limitations deduced from the climate control on canopy photosynthetic capacity observed in our results. The $y$ axis represents the $R^{2}$ values of the linear models normalized EVI as a function of normalized precipitation (a) and as a function of maximal temperature (b), respectively for the sample with $\triangle \mathrm{EVI}_{\text {wet-dry }}$ above the threshold (a) and below the threshold (b). Optimal threshold of $\Delta E V I_{\text {wet-dry }}$ for climate variable influence on normalized EVI was defined by a break in the decrease of $R^{2}$ values, which is represented by red dashed lines.

\subsection{Decoupling wood productivity, litter productivity and canopy photosynthetic capacity seasonality}

In sites where both measurements were available, we observed a negative relationship between wood productivity and litterfall (Fig. 9, supported by linear analysis, Fig. S2). This relationship is consistent across the tropics and constant for all our sites (Fig. 10c), independently of the site water or light limitations (Mann-Whitney test, $U=746, p=0.0839$ ). Wood productivity and litterfall are mainly driven by only one climate driver in our results, precipitation and cloud cover respectively. The seasonality of these climate drivers are coupled for all the sites, where maximum precipitation occurs in the wet season while minimum cloud cover occurs in the dry season.
In water-limited forests, the seasonality EVI and aboveground wood production are synchronous for the majority of the sites (Fig. 10a), as a consequence of their relationship with precipitation. However, aboveground wood production is better explained by precipitation than EVI $\left(R^{2}\right.$ of 0.503 and 0.451 respectively).

Conversely, in light-limited sites and forests with mixed limitations (mixed forests), EVI is weakly coupled with the seasonality of wood productivity (respectively $p=0.0633$, $R^{2}=0.017$ and $\left.p=0.0124, R^{2}=0.055\right)$. Therefore, we conclude that the relationship between EVI and wood productivity depends on site limitations (Mann-Whitney test, $U=874.5, p=0.0012$ ).

The relationship between EVI and litter production is not constant (Fig. 10b), and also depends on site limitations (Mann-Whitney test, $U=1016.5, p<0.001$ ). EVI is consistently negatively associated with litterfall production for water-limited forests ( $p<0.001, R^{2}=0.510$ ), reflecting forest "brown-down" when litterfall is maximal. Litter production is slightly better explained by cloud cover than EVI ( $R^{2}$ of 0.533 and 0.510 respectively), and they predict the same effect for the same site (McNemar test, $p=0.999$ ). No significant associations are found between EVI and litter in forests with mixed limitations $\left(p=0.8531, R^{2}<0.0001\right)$ and in light-limited forests $\left(p=0.4309, R^{2}<0.0001\right)$.

$\Delta \mathrm{EVI}_{\text {wet-dry }}$ and $\Delta$ wood productivity ${ }_{\text {wet-dry }}$ are dependent on annual water availability (Figs. $11 \mathrm{a}-\mathrm{b}$ and $5 \mathrm{~d}$ ). $\Delta$ wood productivity $_{\text {wet-dry }}$ is close to zero and could be negative for light-limited sites; the amplitude of the seasonality is driven by the annual water availability. The values for $\Delta$ wood productivity $_{\text {wet-dry }}$ in south-east Asia are all negative. This is consistent with the negative or null associations of wood productivity and precipitation at these sites (Appendix A1). $\Delta$ litter productivity wet-dry is poorly correlated with maximum climatological water deficit (CWD).

\section{Discussion}

We have found a remarkably strong climate signal in the seasonal carbon cycle components studied across tropical forests. While wood and litterfall production appear to be dependent on a single major climate driver across the tropics (water availability), the control of photosynthetic capacity varies according to the increase in annual water availability, shifting from water-only to light-only drivers.

Minimum aboveground wood production tends to occur in the dry season. While this result is not new (Wagner et al., 2014), here we confirm this pattern with a large database of wood production measurements (68 sites). Months with the lowest water availability are less favourable for cell expansion, as water stress is known to inhibit this process, as observed in dry tropical sites (Borchert, 1999; Krepkowski et al., 2011). This pattern is found in water-limited, mixed and light-limited sites. At the very end of the water availabil- 


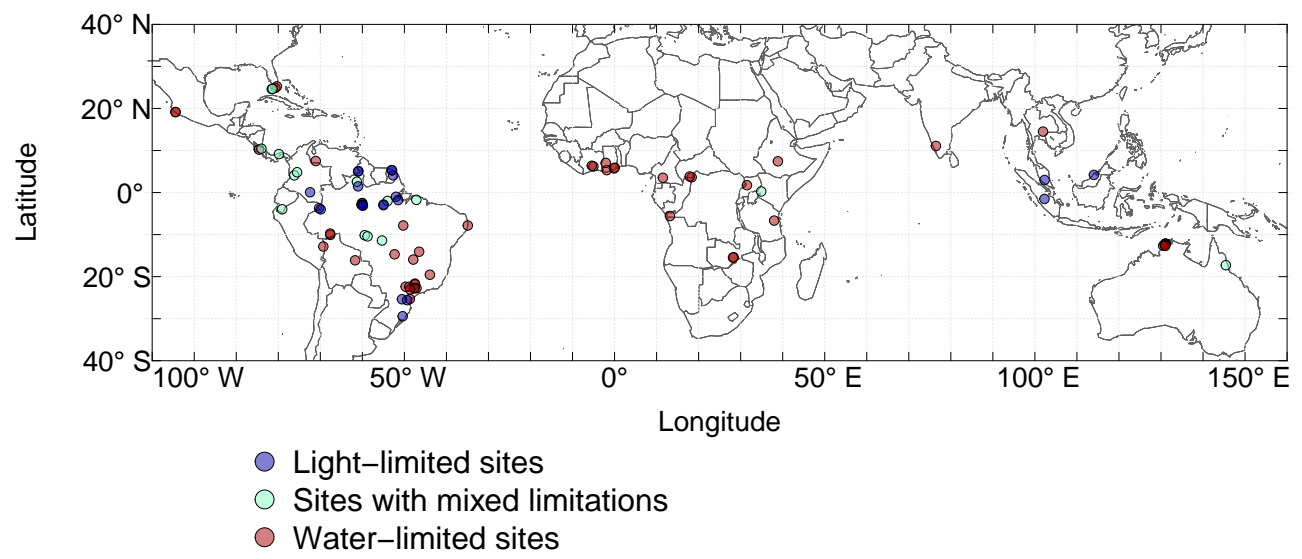

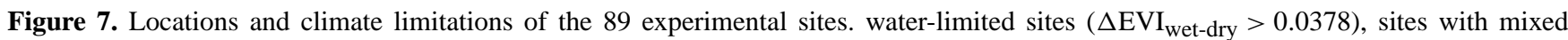
limitations $\left(\Delta \mathrm{EVI}_{\mathrm{wet}-\mathrm{dry}}[-0.0014 ; 0.0378]\right)$ and light-limited sites $\left(\Delta \mathrm{EVI}_{\mathrm{wet}}\right.$-dry $\left.<-0.0014\right)$, (Fig. 6 for the definition of the thresholds).

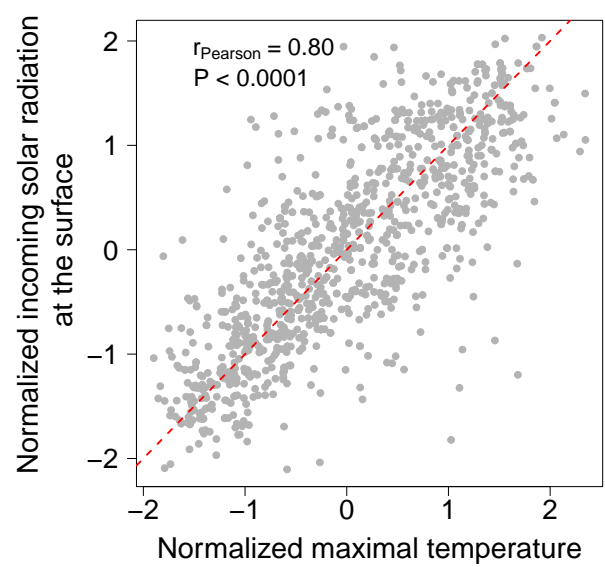

Figure 8. Association between normalized maximal temperature from Climate Research Unit and normalized incoming solar radiation at the surface from CERES. Monthly incoming solar radiation at the surface (incident shortwave radiation) refers to radiant energy with wavelengths in the visible, near-ultraviolet, and near-infrared spectra and is produced using MODIS data and geostationary satellite cloud properties (Kato et al., 2011). The red dashed line is the identity line $y=x$.

ity gradient (wettest ones), some sites have no relationship or a negative relationship with monthly precipitation, as observed in Lambir, Malaysia (Kho et al., 2013). These sites, three in south-east Asia and one in southern Brazil, have no marked dry season, defined as months with precipitation below $100 \mathrm{~mm}$. These relationships with monthly precipitation could reflect cambial dormancy induced by soil water saturation, as observed in Amazonian floodplain forests (Schöngart et al., 2002), and/or be related to limited light availability due to persistent cloud cover. However, for these ultra wet sites, the lack of field data limits the analysis of the effects of climate on the seasonality of aboveground wood production.
Maximum litterfall, for most of our sites, occurs during the months of minimum cloud cover during the dry season. It is known that the gradient from deciduous to evergreen forests is related to water availability, with the evergreen state sustained during the dry season above a mean annual precipitation threshold of approximately $2000 \mathrm{~mm} \mathrm{yr}^{-1}$ (Guan et al., 2015). The litterfall peak occurs when evaporative demand is highest. The maintenance of litterfall seasonality in the light-limited sites could be driven mostly by a few large/tall canopy trees shedding leaves, mainly in response to high evaporative demand. This can explain why litterfall occurs in the dry season and is decoupled from EVI, a parameter that integrates the entire canopy (Fig. 10b). On the other hand, in water-limited sites, most of the trees shed their leaves, thereby resulting in a litterfall signal coupled with EVI "brown-down" (Fig. 10b).

Canopy photosynthetic capacity has different climate controls depending on water limitations (Fig. 5). As already observed, in sites with mean annual precipitation below $2000 \mathrm{~mm} \mathrm{yr}^{-1}$ (Fig. 5d), photosynthetic capacity is highly associated with water availability (Guan et al., 2015) and highly dependent on monthly precipitation (Fig. 5b). This seems to confirm that longer or more intense dry seasons can lead to a dry-season reduction in photosynthetic rates (Guan et al., 2015). In addition to the control by water availability (Guan et al., 2015; Bowman and Prior, 2005; Hilker et al., 2014), we demonstrated that for sites where water is not limiting, photosynthetic capacity depends on maximal temperatures, which reflects available solar energy or daily insolation at the forest floor (Fig. 8). For these sites, the EVI peak occurs at the same time as the maximal temperature peak, which supports the hypothesis of the detection of a leaf flushing signal induced by a preceding increase of daily insolation (Borchert et al., 2015). This result is also consistent with flux-tower-based GPP estimates in neotropical forests (Restrepo-Coupe et al., 2013; Guan et al., 2015; Bonal et al., 2008). If the increase in EVI is a proxy of leaf 


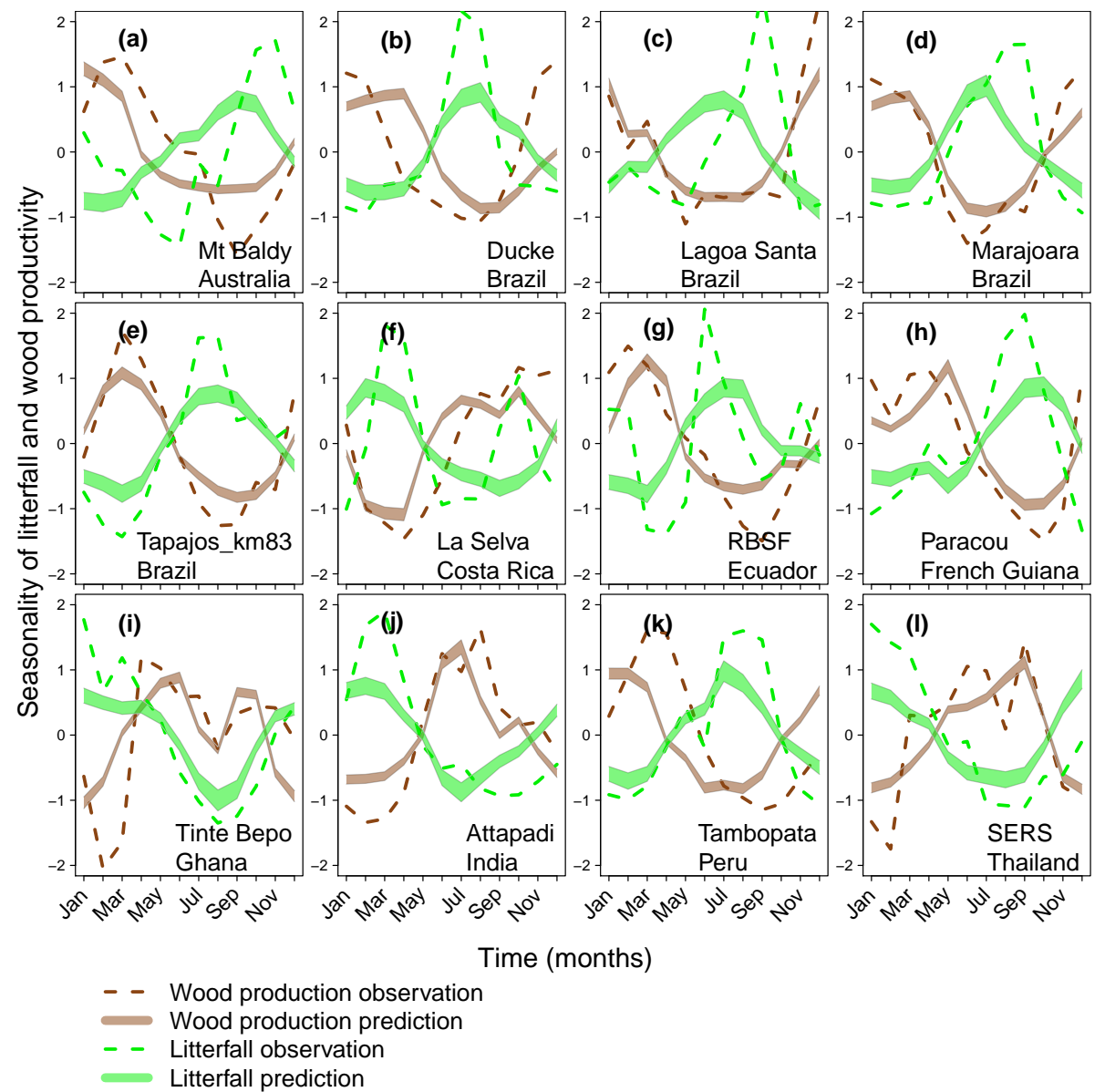

Figure 9. Observations and predictions of wood productivity and litterfall seasonality in sites where both measurements were available. The outliers in our analysis, Lambir and Caracarai, are not represented. $y$ axis have no units as the variables were normalized.
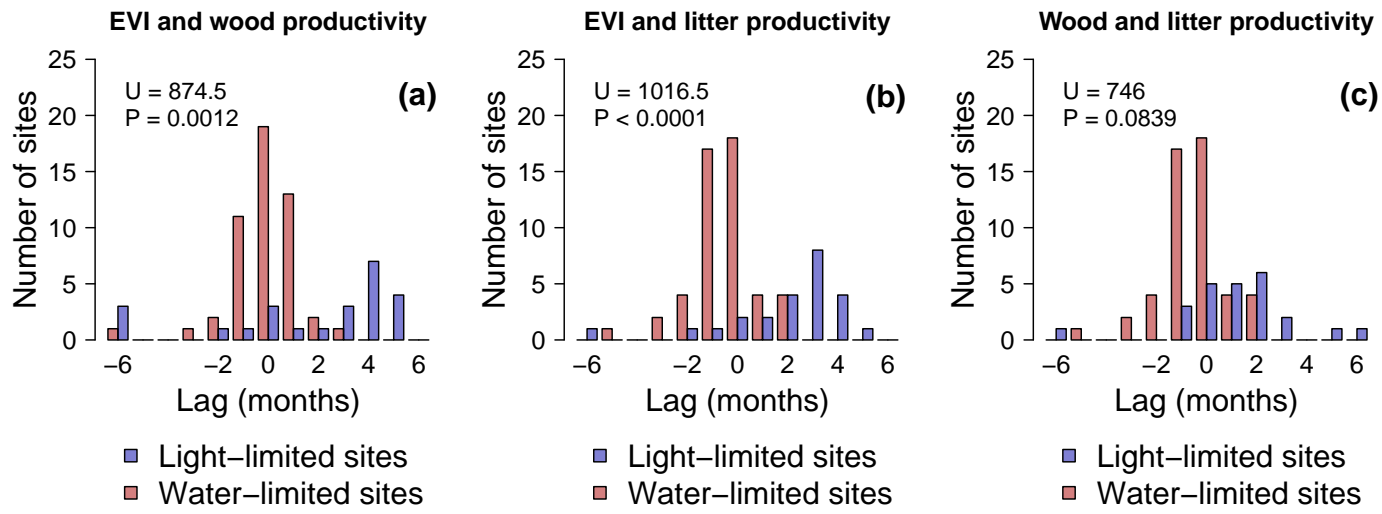

Figure 10. Cross-correlation between monthly EVI and wood productivity (a), EVI and litter productivity (b) and wood and litter productivity (c) for water- and light-limited sites. The $x$ axis indicates the time-lag to get the maximum correlation between the variables. When no observations were available for wood and litter productivity, predictions from the climatic model were used (Table 4). To facilitate graphical representation, cross-correlation (a) is positive, while (b) and (c) are negative. A positive cross-correlation at lag of 1 month indicates a similar seasonal pattern in the time series with a time lag of 1 month, while a negative cross-correlation at lag 1 month indicates an opposite seasonal pattern with a time lag of 1 month. All the water-limited and light-limited sites were represented (respectively 50 and 24 sites) as only 4 water-limited sites in (a) and 3 in (b), and only 2 light-limited sites in (c) have no statistically significant cross-correlation. 

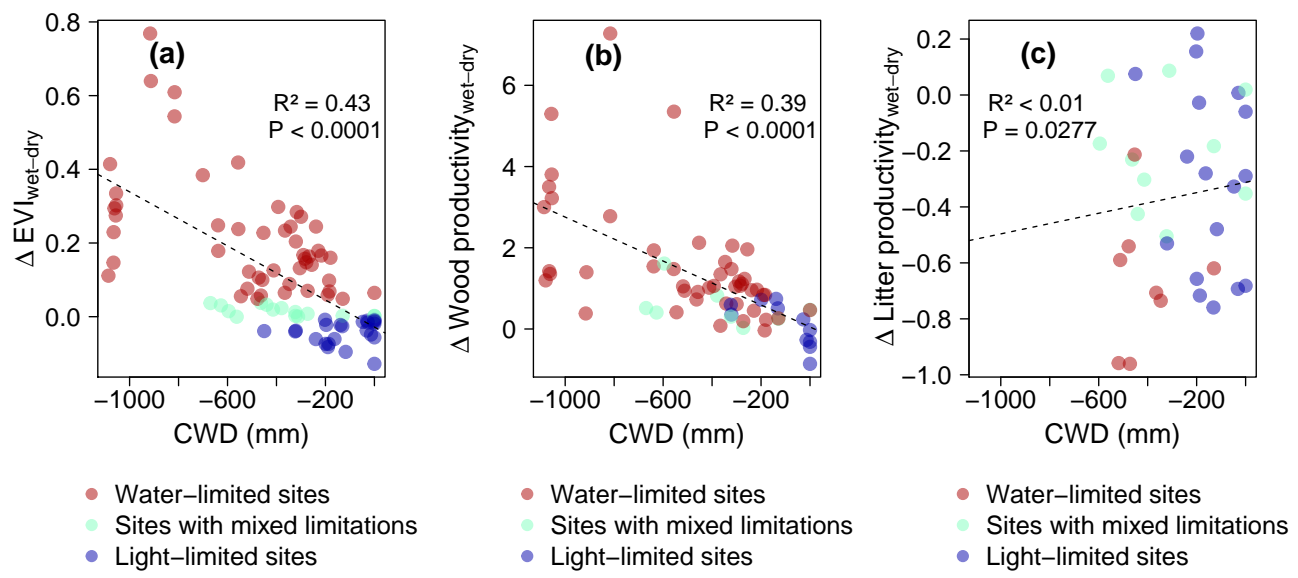

Figure 11. Associations between site's $\Delta \mathrm{EVI}_{\mathrm{wet} \text {-dry }}$ (a), $\Delta$ wood productivity ${ }_{\text {wet-dry }}$ (b) and $\Delta$ litter productivity ${ }_{\text {wet-dry }}$ (c) with the environmental variable maximum climatological water deficit (CWD). Dashed lines are the regression lines. $\Delta \mathrm{EVI}_{\mathrm{wet}-\mathrm{dry}}, \Delta$ wood productivity $_{\text {wet-dry }}$ and $\Delta$ litter productivity ${ }_{\text {wet-dry }}$ indices are the differences of mean of the wet- and dry-season of the variable normalized by the annual mean, where dry season is defined as months with potential evapotranspiration above precipitation (Guan et al., 2015). For the sites where evapotranspiration is never above precipitation, dry season is defined as months with normalized potential evapotranspiration above normalized precipitation.

maturation, as already observed in a tropical forest of southern Peru (Chavana-Bryant et al., 2016), our result supports the satellite-based hypothesis that temporal adjustment of net leaf flush occurs to maximize water and radiation use while reducing drought susceptibility (Myneni et al., 2007; Jones et al., 2014; Bi et al., 2015). However, more detailed data on the leaves dynamics would be necessary to confirm these assumptions.

We demonstrated that the seasonality of aboveground wood production and litterfall are coupled, while photosynthetic capacity seasonality can be decoupled from wood and litterfall production seasonality depending on the local water availability (Fig. 10).

Further, our results show that carbon allocation to wood is prioritized in the wet season, independently of the site conditions (water- or light-limited). This priority has also been shown in forests impacted by droughts, where trees prioritised wood production by reducing autotrophic respiration even when photosynthesis was reduced as a consequence of water shortage (Doughty et al., 2015). However, there is still a lack of information on a wider scale regarding how trees prioritise the use of non-structural carbohydrates. The potential decoupling of carbon assimilation and carbon allocation found here seems to indicate a complex and indirect mechanism driving carbon fluxes in the trees. Some experimental results showed that endogenous and phenological rhythms can define the prioritisation in carbon allocation and may be more important drivers of the carbon cycle seasonality than climate in tropical forests (Malhi et al., 2014; Doughty et al., 2014; Morel et al., 2015). This corroborates other results that indicate that growth is not limited by carbon supply in tropical forests (Körner, 2003; van der Sleen et al., 2015; Wurth et al., 2005). However, even if these results are in accordance with our results for light-limited sites, it must be noted that they cannot be generalized to water-limited sites, where climate constrains both photosynthetic capacity and wood productivity.

Canopy photosynthetic capacity and aboveground wood production appear to be predominantly driven by climate at seasonal and annual scales, thereby suggesting exogenous drivers (Figs. 5 and 11). However, if litterfall was driven by climate only, its pattern would be more predictable, with a linear relationship between annual water availability (CWD) and $\Delta$ litter productivity wet-dry $_{\text {such }}$ as for wood production (Fig. 11b-c), which would translate into a massive peak in the dry season. Even with the litterfall peak occurring mainly in the dry season, another part of the variation seems to be related to endogenous drivers. Such endogenous effects have already been observed in tropical forests, for example, seasonality of root production prioritised over leaf production in a dry site in Bolivia or leaf production occurrence during wet months in French Guiana (Doughty et al., 2014; Morel et al., 2015). The lag between peak of litterfall in dry season and minimum photosynthetic capacity of the canopy we observe for light-limited sites (Fig. 10b) could reflect a mixture of bud sets and bud breaks with a relative weak synchronism due to the high diversity of species involved and the weakness of the seasonal signal of solar insolation. Our results are consistent with a seasonal cycle timed to the seasonality of solar insolation, but with an additional noise due to leaf renewal and/or net leaf abscission during the entire year unrelated to climate variations (Borchert et al., 2015; Myneni et al., 2007; Jones et al., 2014; Bi et al., 2015). While photosynthetic capacity and wood productivity appear mostly exoge- 
nously driven, litterfall association with climate at seasonal and annual scales suggest both exogenous and endogenous processes. It remains the case that the unexplained variability of photosynthetic capacity and wood productivity seasonality could be link to endogenous drivers, but more investigations are needed to demonstrate it.

In this study, we use EVI as an index of seasonality of canopy photosynthetic capacity based on the previously demonstrated correlation between canopy photosynthetic capacity from the MODIS sensor and solar-induced chlorophyll fluorescence (SIF) at a pan-tropical scale (Guan et al., 2015) and from the correlation between $\Delta \mathrm{EVI}_{\text {wet-dry }}$ from MODIS MOD13C1, MCD43A1 and MAIAC products (Fig. S4). Here, we show how satellite and field data can be used to infer characteristics of tropical forests carbon cycle in a consistent framework. To go further, it is necessary to determine the real amount of photosynthetic products in order to describe quantitatively the seasonal carbon cycle in tropical forests.

\section{Conclusions}

In summary, the seasonality of carbon assimilation and allocation through photosynthetic capacity and aboveground wood production is consistently and directly related to climate in tropical forested regions. Notably, we found that regions without annual water limitations exhibit a decoupled carbon assimilation and storage cycle, which highlight the complexity of carbon allocation seasonality in the tropical trees. Although seasonal carbon allocation to aboveground wood production is driven by water, whether the seasonality of photosynthetic capacity is driven by light or water depends on the limitations of site water availability.
In a drier climate, from our results we can make the following assumptions. (i) In water-limited forests, the reduction of the wet period duration could lead to a time reduction of favourable conditions for carbon assimilation and allocation. (ii) In current light-limited forests with future precipitation below to the $2000 \mathrm{~mm} \mathrm{yr}^{-1}$ threshold, the intensification of the dry period could suppress the canopy photosynthetic capacity increase during this high solar radiation period, reducing carbon assimilation and making these forests shift to water-limited forests. However, in light-limited forests with future precipitation above the $2000 \mathrm{~mm} \mathrm{yr}^{-1}$ threshold, as cloud cover has been shown to limits net $\mathrm{CO}_{2}$ uptake and growth of tropical forest trees (Graham et al., 2003), it remains uncertain how reduction of cloud cover will affect the productivity. 


\section{Appendix A: Description of outliers}

\section{A1 Wood productivity outliers}

Despite this dominant signal, outliers exist in our data showing negative (3 sites) or no relationship (6 sites) with precipitation. Due to the correlation of climate variables at the site scale, it is difficult to interpret each site alone; however, some groups arose in these outlier sites. The first group, the two sites Itatinga and Pinkwae, contains only saplings measurements. The second group, the sites with no month with precipitation below $100 \mathrm{~mm}$, includes Lambir (Malaysia), Muara Bungo (Indonesia), Pasoh (Malaysia), Flona SFP (Brazil). The third group includes two mountain sites, Tulua and Munessa. For Munessa, there is evidence of cambial growth related to precipitation Krepkowski et al. (2011); however, the sample we used comprises two species known to have different sensitivity to rainfall. The monthly mean of the sites' wood productivity could be responsible for the lack of rainfall-related pattern. Finally, for Caracarai (Brazil), there was a lack of 6-month data encompassing the beginning and middle of the wet season, which has been linearly interpolated to the month; however, due to the important sampling effort, we initially chose to keep this data set.

\section{A2 Litterfall productivity outliers}

Only one site, BDFFP, showed no apparent relationship between litter productivity and cloud cover (Fig. S3). This site is in a fragmented forest where fragmentation is known to affect litterfall (Vasconcelos and Luizão, 2004). For the other outlier, they all have a peak of litterfall correlated with pet or cld (Fig. S3). Three different groups can be observed: (i) sites which have another peak of litterfall during the year (Cueiras, La Selva, Gran Sabana), (ii) sites with very skew litterfall peaks followed by an important decrease in litterfall, while the climate conditions are optimal for litterfall productivity from the viewpoint of the linear model (Capitao Paco, Rio Juruena and RBSF) and (iii) sites which have two peaks of pet, but litterfall occurs only during one of them (Apiau Roraima, Gran Sabana). 


\section{Appendix: Data availability}

The data and the code to reproduce the analysis and the figures are freely available upon request to the corresponding author.

\section{The Supplement related to this article is available online at doi:10.5194/bg-13-2537-2016-supplement.}

Author contributions. Fabien H. Wagner, Luiz E. O. C. Aragão, Bruno Hérault, Damien Bonal and Clément Stahl wrote the paper, Fabien H. Wagner, Luiz E. O. C. Aragão and Bruno Hérault conceived and designed the study, Fabien $\mathrm{H}$. Wagner assembled the data sets, Benjamin Brede and Jan Verbesselt contributed to the programming part, Fabien $\mathrm{H}$. Wagner carried out the data analysis. All co-authors collected field data and commented on or approved the manuscript.

Acknowledgements. This project and F. H. W. have been funded by the Fapesp (Fundação de Amparo à Pesquisa do Estado de São Paulo, processo 13/14520-6). L. E. O. C. A. thank the support of FAPESP (grant 50533-5) and CNPQ (grant 304425/2013-3). J. P. L. and M. M. T. were funded by the CNPq and the FAPEMIG. B. P. M. was funded by the Australian Research Council for the project "Understanding the impact of global environmental change on Australian forests and woodlands using rainforest boundaries and Callitris growth as bio-indicators", grant number: DP0878177. A. B. was funded by the German Research Foundation (DFG) for the project BR1895/15 and the projects BR1895/14 and BR1895/23 (PAK 823). F. A. C. and J. M. F. were funded by the CNPq (grant 476477/2006-9) and the Fundação O Boticário de Proteção a Natureza (grant 0705-2006). F. R. C. C. was funded by the CNPq/PELD "Impactos antrópicos no ecossistema de floresta tropical - site Manaus", Processo 403764/2012-2. J. G. was supported from the US Forest Service-International Institute of Tropical Forestry. A. D. G. funding was provided through ARC Linkage (Timber harvest management for the Aboriginal arts industry: socio-economic, cultural and ecological determinants of sustainability in a remote community context, LP0219425). S. F. O. was funded by the National Science Foundation BE/CBC: Complex interactions among water, nutrients and carbon stocks and fluxes across a natural fertility gradient in tropical rain forest (EAR 421178) and National Science Foundation Causes and implications of dry season control of tropical wet forest tree growth at very high water levels: direct vs. indirect limitations (DEB 842235). E. E. M. was funded by the Academy of Finland (project: 266393). L. M. was funded by a grant provided by the European Union (FP6, INCO/SSA) for a 2 year (2006-2008) project on management of indigenous tree species for restoration and wood production in semi-arid miombo woodlands in East Africa (MITMIOMBO). F. V. was supported by the German Research Foundation (DFG) by funding the projects BR 1895/14-1/2 (FOR 816) and BR 1895/23$1 / 2$ (PAK 823). L. K. K. was supported by the Malaysian Palm Oil Board. D. M. D. was funded by the Hermon Slade Foundation (Grant HSF 09/5). Data recorded at Paracou, French Guiana, were partly funded by an "Investissement d'Avenir" grant from the ANR (CEBA: ANR-10-LABX-0025). H. A. M. and J. J. C. thank the staff of the Jardín Botânico "Juan María Céspedes" (INCIVA, Colombia) and the Instituto Boliviano de Investigación Forestal (IBIF, Bolivia) for their support, particularly to M. Toledo and W. Devia; and P. Roosenboom (INPA Co.) and his staff at Concepción (G. Urbano) for their help in Bolivia. H. A. M. and J. J. C. were funded by the following research projects "Análisis retrospectivos mediante dendrocronología para profundizar en la ecología y mejorar la gestión de los bosques tropicales secos" (financed by Fundación BBVA) and "Regeneración, crecimiento y modelos dinámicos de bosques tropicales secos: herramientas para su conservación y para el uso sostenible de especies maderables" (AECID 11-CAP2-1730, Spanish Ministry of Foreign Affairs). C. S. L. was funded by a grant from FAPESP (Proc. 02/ 14166-3), and Brazilian Council for Superior Education, CAPES. J. H. was funded by two grants from the Deutsche Forschungsgemeinschaft (DFG): BR379/16 and HO3296/4. D. A. C. was funded by the US National Science Foundation (most recently EAR0421178 \& DEB1357112), the US Department of Energy, the Andrew W. Mellon Foundation, and Conservation International's TEAM Initiative. C. S. was funded by a grant from the "European Research 991 Council Synergy", grant ERC-2013-SyG-610028 IMBALANCE-P. M. R. K., J. E. F. M., T. L. S. and F. G. were funded by Petrobras SA. We further thank Jeanine Maria Felfili and Raimundo dos Santos Saraiva who contributed to this work but who are no longer with us.

Edited by: S. Zaehle

\section{References}

Aerts, R.: Prota 7, Timbers/Bois d'oeuvre 1. [CD-Rom], chap. Afrocarpus falcatus (Thunb.), edited by: Page, C. N., Louppe, D., and Oteng-Amoako, A. A., and Brink, M., PROTA, Wageningen, 38 43, Netherlands, 2008.

Baccini, A., Goetz, S. J., Walker, W. S., Laporte, N. T., Sun, M., Sulla-Menashe, D., Hackler, J., Beck, P. S. A., Dubayah, R., Friedl, M. A., Samanta, S., and Houghton, R. A.: Estimated carbon dioxide emissions from tropical deforestation improved by carbon-density maps, Nature Climate Change, 2, 182-185, 2012.

Baker, T., Affum-Baffoe, K., Burslem, D., and Swaine, M.: Phenological differences in tree water use and the timing of tropical forest inventories: conclusions from patterns of dry season diameter change, Forest Ecol. Manag., 171, 261-274, 2002.

Baker, T., Burslem, D., and Swaine, M.: Associations between tree growth, soil fertility and water availability at and regional scales in Ghanian tropical rain forest, J. Trop. Ecol., 19, 109-125, 2003.

Baraloto, C., Paine, T. C. E., Poorter, L., Beauchene, J.and Bonal, D., Domenach, A.-M., Hérault, B., Patiño, S., Roggy, J.-C., and Chave, J.: Decoupled leaf and stem economics in rain forest trees, Ecol. Lett., 13, 1338-1347, 2010.

Becker, G. S., Braun, D., Gliniars, R., and Dalitz, H.: Relations between wood variables and how they relate to tree size variables of tropical African tree species, Trees-Struct. Funct., 26, 11011112, 2012.

Bi, J., Knyazikhin, Y., Choi, S., Park, T., Barichivich, J., Ciais, P., Fu, R., Ganguly, S., Hall, F., Hilker, T., Huete, A., Jones, M., Kimball, J., Lyapustin, A. I., ottus, M. M., Nemani, R. R., 
Piao, S., Poulter, B., Saleska, S. R., Saatchi, S. S., Xu, L., Zhou, L., and Myneni, R. B.: Sunlight mediated seasonality in canopy structure and photosynthetic activity of Amazonian rainforests, Environ. Res. Lett., 10, 064014, doi:10.1088/17489326/10/6/064014, 2015.

Boanerges, D. S.: Wood densities measurements of PPBio permanent plots from the Parque Nacional do Viruá (Caracaraí, RR), 2012.

Bonal, D., Bosc, A., Ponton, S., Goret, J. Y., Burban, B., Gross, P., Bonnefond, J. M., Elbers, J., Longdoz, B., Epron, D., Guehl, J. M., and Granier, A.: Impact of severe dry season on net ecosystem exchange in the Neotropical rainforest of French Guiana, Glob. Change Biol., 14, 1917-1933, 2008.

Bonal, D., Ponton, S., Le Thiec, D., Richard, B., Ningre, N., Herault, B., Ogee, J., Gonzalez, S., Pignal, M., Sabatier, D., and Guehl, J.-M.: Leaf functional response to increasing atmospheric $\mathrm{CO}_{2}$ concentrations over the last century in two northern Amazonian tree species: a historical delta C-13 and delta O-18 approach using herbarium samples, Plant Cell Environ., 34, 1332-1344, 2011.

Borchert, R.: Climatic periodicity, phenology, and cambium activity in tropical dry forest trees, IAWA Journal, 20, 239-247, 1999.

Borchert, R., Calle, Z., Strahler, A. H., Baertschi, A., Magill, R. E., Broadhead, J. S., Kamau, J., Njoroge, J., and Muthuri, C.: Insolation and photoperiodic control of tree development near the equator, New Phytol., 205, 7-13, 2015.

Bowman, D. and Prior, L.: Turner review No. 10: Why do evergreen trees dominate the Australian seasonal tropics?, Aust. J. Bot., 53, 379-399, 2005.

Boyle, B., Hopkins, N., Lu, Z., Garay, J. A. R., Mozzherin, D., Rees, T., Matasci, N., Narro, M. L., Piel, W. H., Mckay, S. J., Lowry, S., Freeland, C., Peet, R. K., and Enquist, B. J.: The taxonomic name resolution service: an online tool for automated standardization of plant names, BMC Bioinformatics, 14, 1-15, doi:10.1186/1471-2105-14-16, 2013.

Brando, P. M., Goetz, S. J., Baccini, A., Nepstad, D. C., Beck, P. S. A., and Christman, M. C.: Seasonal and interannual variability of climate and vegetation indices across the Amazon, P. Natl. Acad. Sci. USA, 107, 14685-14690, 2010.

Brauning, A., Volland-Voigt, F., Burchardt, I., Ganzhi, O., Nauss, T., and Peters, T.: Climatic control of radial growth of Cedrela montana in a humid mountain rainforest in southern Ecuador, Erdkunde, 63, 337-345, 5480B Times Cited:3 Cited References Count: 47, 2009.

Brienen, R. J. W., Phillips, O. L., Feldpausch, T. R., Gloor, E., Baker, T. R., Lloyd, J., Lopez-Gonzalez, G., MonteagudoMendoza, A., Malhi, Y., Lewis, S. L., Vasquez Martinez, R., Alexiades, M., Alvarez Davila, E., Alvarez-Loayza, P., Andrade, A., Aragao, L. E. O. C., Araujo-Murakami, A., Arets, E. J. M. M., Arroyo, L., Aymard C., G. A., Banki, O. S., Baraloto, C., Barroso, J., Bonal, D., Boot, R. G. A., Camargo, J. L. C., Castilho, C. V., Chama, V., Chao, K. J., Chave, J., Comiskey, J. A., Cornejo Valverde, F., da Costa, L., de Oliveira, E. A., Di Fiore, A., Erwin, T. L., Fauset, S., Forsthofer, M., Galbraith, D. R., Grahame, E. S., Groot, N., Herault, B., Higuchi, N., Honorio Coronado, E. N., Keeling, H., Killeen, T. J., Laurance, W. F., Laurance, S., Licona, J., Magnussen, W. E., Marimon, B. S., Marimon-Junior, B. H., Mendoza, C., Neill, D. A., Nogueira, E. M., Nunez, P., Pallqui Camacho, N. C., Parada, A., Pardo-
Molina, G., Peacock, J., Pena-Claros, M., Pickavance, G. C., Pitman, N. C. A., Poorter, L., Prieto, A., Quesada, C. A., Ramirez, F., Ramirez-Angulo, H., Restrepo, Z., Roopsind, A., Rudas, A., Salomao, R. P., Schwarz, M., Silva, N., Silva-Espejo, J. E., Silveira, M., Stropp, J., Talbot, J., ter Steege, H., Teran-Aguilar, J., Terborgh, J., Thomas-Caesar, R., Toledo, M., Torello-Raventos, M., Umetsu, R. K., van der Heijden, G. M. F., van der Hout, P., Guimaraes Vieira, I. C., Vieira, S. A., Vilanova, E., Vos, V. A., and Zagt, R. J.: Long-term decline of the Amazon carbon sink, Nature, 519, 344-348, 2015.

Brodribb, T., Bowman, D., Grierson, P., Murphy, B., S, N., and LD, P.: Conservative water management in the widespread conifer genus Callitris, AoB PLANTS, 5, plt052, doi:10.1093/aobpla/plt052, 2013.

Bunyavejchewin, S.: Ecological studies of tropical semi-evergreen rain forest at Sakaerat, Nakhon Ratchasima, Northeast Thailand, II Litterfall, Nat. Hist. Bull. Siam Soc., 45, 43-52, 1997.

Cardoso, F. C. G., Marques, R., Botosso, P. C., and Marques, M. C. M.: Stem growth and phenology of two tropical trees in contrasting soil conditions, Plant and Soil, 354, 269-281, 2012.

Carvalho, F. A.: Dinâmica da vegetação arbórea de uma floresta estacional decidual sobre afloramentos calcários no Brasil central, Ph.D. thesis, Universidade de Brasília, Instituto de Ciências Biológicas, Departamento de Ecologia, Programa de Pósgraduação em Ecologia, 2009.

Castilho, C., Boanerges, D. S., Silva, W. R., and Toledo, J. J.: Dendrometer and litterfall data of PPBio permanent plots from the Parque Nacional do Viruá (Caracaraí, RR), 2012.

Cause, M., Rudder, E., and Kynaston, W.: Technical pamphlet no. 2: Queensland timbers - their nomenclature, density and lyctid susceptibility, Tech. rep., Queensland Forest Service, Brisbane, 1989.

Chagas, R. K., Durigan, G., Contieri, W. A., and Saito, M.: Pesquisas em conservação e recuperação ambiental no oeste paulista: resultados da cooperação Brasil Japão, chap. Crescimento diametral de espécies arbóreas em floresta estacional semidecidual ao longo de seis anos, edited by: Bôas, O. V. and Durigan, G., Inst. Flor. de S. Paulo e JICA, 265-290, 2004.

Chamberlain, S. and Szocs, E.: taxize - taxonomic search and retrieval in R, F1000Research, 2013.

Chambers, J., da Silva, R., Siza Tribuzy, E., dos Santos, J., and N., H.: LBA-ECO CD-08 Tree Diameter Measurements, Jacaranda Plots, Manaus, Brazil, 1999-2001, available at: http://daac.ornl. gov, from Oak Ridge National Laboratory Distributed Active Archive Center, Oak Ridge, Tennessee, USA, 2013.

Chavana-Bryant, C., Malhi, Y., Wu, J., Asner, G. P., Anastasiou, A., Enquist, B. J., Cosio Caravasi, E. G., Doughty, C. E., Saleska, S. R., Martin, R. E., and Gerard, F. F.: Leaf aging of Amazonian canopy trees as revealed by spectral and physiochemical measurements, New Phytol., in press, doi:10.1111/nph.13853, 2016.

Chave, J., Coomes, D., Jansen, S., Lewis, S. L., Swenson, N. G., and Zanne, A. E.: Towards a worldwide wood economics spectrum, Ecol. Lett., 12, 351-366, 2009.

Chave, J., Navarrete, D., Almeida, S., Alvarez, E., Aragao, L. E. O. C., Bonal, D., Chatelet, P., Silva-Espejo, J. E., Goret, J. Y., von Hildebrand, P., Jimenez, E., Patino, S., Penuela, M. C., Phillips, O. L., Stevenson, P., and Malhi, Y.: Regional and seasonal patterns of litterfall in tropical South America, Biogeosciences, 7, 43-55, doi:10.5194/bg-7-43-2010, 2010. 
Chave, J., Rejou-Mechain, M., Burquez, A., Chidumayo, E., Colgan, M. S., Delitti, W. B. C., Duque, A., Eid, T., Fearnside, P. M., Goodman, R. C., Henry, M., Martinez-Yrizar, A., Mugasha, W. A., Muller-Landau, H. C., Mencuccini, M., Nelson, B. W., Ngomanda, A., Nogueira, E. M., Ortiz-Malavassi, E., Pelissier, R., Ploton, P., Ryan, C. M., Saldarriaga, J. G., and Vieilledent, G.: Improved allometric models to estimate the aboveground biomass of tropical trees, Glob. Change Biol., 20, 3177-3190, 2014.

Chidumayo, E.: Effects of climate on the growth of exotic and indigenous trees in central Zambia, J. Biogeogr., 32, 111-120, 2005.

Clark, D. A., Cascante, M., Artavia, J., Villegas, D., and Campos, P.: litterfall monitoring in the 18 carbono plots, La Selva Biological Station, Tech. rep., CARBONO PROJECT, 2009.

Clark, D. B., Clark, D. A., and Oberbauer, S. F.: Annual wood production in a tropical rain forest in NE Costa Rica linked to climatic variation but not to increasing $\mathrm{CO}_{2}$, Global Change Biology, 16, 747-759, 2010.

Couralet, C., Sterck, F. J., Sass-Klaassen, U., Van Acker, J., and Beeckman, H.: Species-Specific Growth Responses to Climate Variations in Understory Trees of a Central African Rain Forest, Biotropica, 42, 503-511, 6190G Times Cited:3 Cited References Count:82, 2010.

Cuny, H. E., Rathgeber, C. B. K., Frank, D., Fonti, P., Makinen, H., Prislan, P., Rossi, S., del Castillo, E. M., Campelo, F., Vavrcik, H., Camarero, J. J., Bryukhanova, M. V., Jyske, T., Gricar, J., Gryc, V., De Luis, M., Vieira, J., Cufar, K., Kirdyanov, A. V., Oberhuber, W., Treml, V., Huang, J.-G., Li, X., Swidrak, I., Deslauriers, A., Liang, E., Nojd, P., Gruber, A., Nabais, C., Morin, H., Krause, C., King, G., and Fournier, M.: Woody biomass production lags stem-girth increase by over one month in coniferous forests, Nature Plants, 1, 11, doi:10.1038/NPLANTS.2015.160, 2015.

de Castro, V. R.: Efeitos do potássio, sódio e da disponibilidade hídrica no crescimento e qualidade do lenho de árvores de Eucalyptus grandis Hill ex Maiden, Ph.D. thesis, Universidade de São Paulo, Escola Superior de Agricultura "Luiz de Queiroz", 2014.

Detienne, P. and A., M.: Nature et périodicité des cernes dans le bois de Samba, Revue Bois et Forets des Tropiques, 169, 29-35, 1976.

Devineau, J. L.: The variability of girth increment of trees in the semi-deciduous tropical forests of Lamto, Ivory-Coast, Revue d'Ecologie, 46, 95-124, 1991.

Doughty, C. E.: An in situ leaf and branch warming experiment in the Amazon, Biotropica, 43, 658-665, 2011.

Doughty, C. E. and Goulden, M. L.: Are tropical forests near a high temperature threshold?, J. Geophys. Res.-Biogeo., 113, 112, 2008.

Doughty, C. E., Malhi, Y., Araujo-Murakami, A., Metcalfe, D. B., Silva-Espejo, J. E., Arroyo, L., Heredia, J. P., Pardo-Toledo, E., Mendizabal, L. M., Rojas-Landivar, V. D., Vega-Martinez, M., Flores-Valencia, M., Sibler-Rivero, R., Moreno-Vare, L., Viscarra, L. J., Chuviru-Castro, T., Osinaga-Becerra, M., and Ledezma, R.: Allocation trade-offs dominate the response of tropical forest growth to seasonal and interannual drought, Ecology, 95, 2192-2201, 2014.

Doughty, C. E., Metcalfe, D. B., Girardin, C. A. J., Amezquita, F. F., Cabrera, D. G., Huasco, W. H., Silva-Espejo, J. E., Araujo-
Murakami, A., da Costa, M. C., Rocha, W., Feldpausch, T. R., Mendoza, A. L. M., da Costa, A. C. L., Meir, P., Phillips, O. L., and Malhi, Y.: Drought impact on forest carbon dynamics and fluxes in Amazonia, Nature, 519, 78-82, 2015.

Drew, D. M., Richards, A. E., Downes, G. M., Cook, G. D., and Baker, P.: The development of seasonal tree water deficit in Callitris intratropica, Tree Physiol., 31, 953-964, 2011.

Dünisch, O., Bauch, J., and Gasparotto, L.: Formation of increment zones and intraannual growth dynamics in the xylem of Swietenia macrophylla, Carapa guianensis, and Cedrela odorata (Meliaceae), Iawa J., 23, 101-119, 2002.

Elifuraha, E., Nöjd, P., and Mbwambo, L.: Short term growth of miombo tree species at Kitulangalo, Working Papers of the Finnish Forest Research Institute, 98, 37-45, 2008.

FAO: Forest resources Assessment Working Paper 179, Global Ecological Zones for forest reporting: 2010 update, Tech. Rep., Food and Agriculture Organization of the United Nations, 2012.

Ferreira-Fedele, L., Tomazello Filho, M., Botosso, P. C., and Giannotti, E.: Periodicidade do crescimento de Esenbeckia leiocarpa Engl. (guarantã) em duas áreas da região Sudeste do Estado de São Paulo, Scientia Forestalis, 65, 141-149, 2004.

Figueira, A., Miller, S., de Sousa, C., Menton, M., Maia, A., da Rocha, H., and Goulden, M.: LBA-ECO CD-04 Dendrometry, km 83 Tower Site, Tapajos National Forest, Brazil, Data set, available at: http://daac.ornl.gov, from Oak Ridge National Laboratory Distributed Active Archive Center, Oak Ridge, Tennessee, USA, 2011.

Free, C., Landis, R., Grogan, J., Schulze, M., Lentini, M., and Dünisch, O.: Management implications of long-term tree growth and mortality rates: A modeling study of big-leaf mahogany (Swietenia macrophylla) in the Brazilian Amazon, Forest Ecol. Manag., 330, 46-54, 2014.

Gliniars, R., Becker, G. S., Braun, D., and Dalitz, H.: Monthly stem increment in relation to climatic variables during 7 years in an East African rainforest, Trees, 27, 1129-1138, 2013.

Graham, E. A., Mulkey, S. S., Kitajima, K., Phillips, N. G., and Wright, S. J.: Cloud cover limits net $\mathrm{CO}_{2}$ uptake and growth of a rainforest tree during tropical rainy seasons, P. Natl. Acad. Sci. USA, 100, 572-576, 2003.

Grogan, J. and Schulze, M.: The Impact of Annual and Seasonal Rainfall Patterns on Growth and Phenology of Emergent Tree Species in Southeastern Amazonia, Brazil, Biotropica, 44, 331 340, 2012.

Guan, K., Pan, M., Li, H., Wolf, A., Wu, J., Medvigy, D., Caylor, K. K., Sheffield, J., Wood, E. F., Malhi, Y., Liang, M., Kimball, J. S., Saleska, S. R., Berry, J., Joiner, J., and Lyapustin, A. I.: Photosynthetic seasonality of global tropical forests constrained by hydroclimate, Nat. Geosci., 8, 284-289, 2015.

Hansen, M. C., Potapov, P. V., Moore, R., Hancher, M., Turubanova, S. A., Tyukavina, A., Thau, D., Stehman, S. V., Goetz, S. J., Loveland, T. R., Kommareddy, A., Egorov, A., Chini, L., Justice, C. O., and Townshend, J. R. G.: High-Resolution Global Maps of 21st-Century Forest Cover Change, Science, 342, 850-853, 2013.

Hilker, T., Lyapustin, A. I., Tucker, C. J., Hall, F. G., Myneni, R. B., Wang, Y., Bi, J., de Moura, Y. M., and Sellers, P. J.: Vegetation dynamics and rainfall sensitivity of the Amazon, P. Natl. Acad. Sci. USA, 111, 16041-16046, 2014. 
Homeier, J.: Dendrometer data from the Reserva Biologica Alberto Brenes, 2012.

Homeier, J., Hertel, D., Camenzind, T., Cumbicus, N. L., Maraun, M., Martinson, G. O., Poma, L. N., Rillig, M. C., Sandmann, D., Scheu, S., Veldkamp, E., Wilcke, W., Wullaert, H., and Leuschner, C.: Tropical Andean forests are highly susceptible to nutrient inputs - rapid effects of experimental $\mathrm{N}$ and $\mathrm{P}$ addition to an Ecuadorian montane forest, PLoS ONE, 7, e47128, doi:10.1371/journal.pone.0047128, 2012.

Homeier, J., Breckle, S.-W., Guenter, S., Rollenbeck, R. T., and Leuschner, C.: Tree diversity, forest structure and productivity along altitudinal and topographical gradients in a species-rich Ecuadorian montane, BIOTROPICA, 42, 140-148, 2010.

Huete, A., Didan, K., Miura, T., Rodriguez, E., Gao, X., and Ferreira, L.: Overview of the radiometric and biophysical performance of the MODIS vegetation indices, Remote Sens. Environ., 83, 195-213, 2002.

Huete, A. R., Didan, K., Shimabukuro, Y. E., Ratana, P., Saleska, S. R., Hutyra, L. R., Yang, W. Z., Nemani, R. R., and Myneni, R.: Amazon rainforests green-up with sunlight in dry season, Geophys. Res. Lett., 33, 1-4, 2006.

Jarvis, A., Reuter, H., Nelson, A., and E., G.: Hole-filled SRTM for the globe Version 4, available at: the CGIAR-CSI SRTM 90m Database (http://srtm.csi.cgiar.org/), Tech. Rep., CGIARCSI, 2008.

Jones, M. O., Kimball, J. S., and Nemani, R. R.: Asynchronous Amazon forest canopy phenology indicates adaptation to both water and light availability, Environ. Res. Lett., 9, 124021, doi:10.1088/1748-9326/9/12/124021, 2014.

Justice, C., Vermote, E., Townshend, J., Defries, R., Roy, D., Hall, D., Salomonson, V., Privette, J., Riggs, G., Strahler, A., Lucht, W., Myneni, R., Knyazikhin, Y., Running, S., Nemani, R., Wan, Z., Huete, A., van Leeuwen, W., Wolfe, R., Giglio, L., Muller, J., Lewis, P., and Barnsley, M.: The Moderate Resolution Imaging Spectroradiometer (MODIS): Land remote sensing for global change research, IEEE T. Geosci. Remote, 36, 1228-1249, 1998.

Kanieski, M. R., Longhi-Santos, T., Neto, J. G., Souza, T., Galvão, F., and Roderjan, C. V.: Influência da precipitação e da temperatura no incremento diamétrico de espécies floreastais aluviais em Araucária-PR, Floresta e Ambiente, 19, 17-25, 2012.

Kanieski, M. R., Longhi-Santos, T., de Freitas Milani, J. E., Miranda, B. P., Galvão, F., Botosso, P. C., and Roderjan, C. V.: Crescimento diamétrico de Blepharocalyx salicifolius em remanescente de floresta ombrófila mista aluvial, Paraná, Floresta e Ambiente, 20, 197-206, 2013.

Kato, S., Rose, F. G., Sun-Mack, S., Miller, W. F., Chen, Y., Rutan, D. A., Stephens, G. L., Loeb, N. G., Minnis, P., Wielicki, B. A., Winker, D. M., Charlock, T. P., Stackhouse, Jr., P. W., Xu, K.M., and Collins, W. D.: Improvements of top-of-atmosphere and surface irradiance computations with CALIPSO-, CloudSat-, and MODIS-derived cloud and aerosol properties, J. Geophys. Res.Atmos., 116, D19209, doi:10.1029/2011JD016050, 2011.

Kho, L. K., Malhi, Y., and Tan, S. K. S.: Annual budget and seasonal variation of aboveground and belowground net primary productivity in a lowland dipterocarp forest in Borneo, J. Geophys. Res.Biogeo., 118, 1282-1296, 2013.

Koenig, J. and Griffiths, A.: The Population Ecology of Two Tropical Trees, Brachychiton diversifolius (Malvaceae) and Bombax ceiba (Bombaceae), Harvested by Indigenous Woodcarvers in Arnhem Land, Australia, Environ. Manag., 50, 555-565, 2012.

Kohler, S. V., Figueiredo, F. A., Chiquetto, A. L., and Dias, A. N.: Incremento sazonal e anual do diâmetro de espécies arbóreas de uma floresta ombrófila mista do centro-sul do Paraná, in: II Encontro de Iniciação Científica do PROIC/UNICENTRO, 2008, Irati, 1-4, 2008.

Körner, C.: Carbon limitation in trees, J. Ecol., 91, 4-17, 2003.

Krepkowski, J., Brauning, A., Gebrekirstos, A., and Strobl, S.: Cambial growth dynamics and climatic control of different tree life forms in tropical mountain forest in Ethiopia, Trees-Struct. Funct., 25, 59-70, 2011.

Lieberman, D.: Seasonality and phenology in a dry tropical forest in Ghana, J. Ecol., 70, 791-806, 1982.

Lisi, C. S., Tomazello, M., Botosso, P. C., Roig, F. A., Maria, V. R. B., Ferreira Fedele, L., and Voigt, A. R. A.: Tree-ring formation, radial increment periodicity, and phenology of tree species from a seasonal semi-deciduous forest in southeast Brazil, Iawa J., 29, 189-207,

Liu, Y. Y., van Dijk, A. I. J. M., de Jeu, R. A. M., Canadell, J. G., McCabe, M. F., Evans, J. P., and Wang, G.: Recent reversal in loss of global terrestrial biomass, Nature Climate Change, 5, 470-474, doi:10.1038/nclimate2581, 2015.

Lloyd, J. and Farquhar, G. D.: Effects of rising temperatures and $\left[\mathrm{CO}_{2}\right]$ on the physiology of tropical forest trees, Philos. T. R. Soc. B, 363, 1811-1817, 2008.

Loeb, N., Wielicki, B., Doelling, D., Smith, G., Keyes, D., Kato, S., Manalo-Smith, N., and T, W.: Toward Optimal Closure of the Earth's Top-of-Atmosphere Radiation Budget, J. Climate, 22, 748-766, 2009.

Lopez-Ayala, J., Valdez-Hernandez, J., Terrazas, T., and ValdezLazalde, J.: Diameter growth of tree species in a semideciduous tropical forest at Colima, Mexico, Agrociencia, 40, 139-147, 2006.

Makinen, H., Seo, J.-W., Nojd, P., Schmitt, U., and Jalkanen, R.: Seasonal dynamics of wood formation: a comparison between pinning, microcoring and dendrometer measurements, Eur. J. For. Res., 127, 235-245, 2008.

Malhi, Y., Farfan Amezquita, F., Doughty, C. E., Silva-Espejo, J. E., Girardin, C. A. J., Metcalfe, D. B., Aragao, L. E. O. C., HuaracaQuispe, L. P., Alzamora-Taype, I., Eguiluz-Mora, L., Marthews, T. R., Halladay, K., Quesada, C. A., Robertson, A. L., Fisher, J. B., Zaragoza-Castells, J., Rojas-Villagra, C. M., Pelaez-Tapia, Y., Salinas, N., Meir, P., and Phillips, O. L.: The productivity, metabolism and carbon cycle of two lowland tropical forest plots in south-western Amazonia, Peru, Plant Ecol. Div., 7, 85-105, 2014.

Melgaço, K. L. L.: Topografia e densidade da madeira modulam o crescimento sazonal na Amazônia Central, Master's thesis, INSTITUTO NACIONAL DE PESQUISAS DA AMAZÔNIA INPA, 2014.

Mendivelso, H. A., Julio Camarero, J., Royo Obregon, O., Gutierrez, E., and Toledo, M.: Differential Growth Responses to Water Balance of Coexisting Deciduous Tree Species Are Linked to Wood Density in a Bolivian Tropical Dry Forest, PLOS ONE, 8, doi:10.1371/journal.pone.0073855, 2013.

Mitchell, T. and Jones, P.: An improved method of constructing a database of monthly climate observations and associated highresolution grids, Int. J. Climatol., 25, 693-712, 2005. 
Morel, H., Mangenet, T., Beauchêne, J., Ruelle, J., Nicolini, E., Heuret, P., and Thibaut, B.: Seasonal variations in phenological traits: leaf shedding and cambial activity in Parkia nitida Miq. and Parkia velutina Benoist (Fabaceae) in tropical rainforest, Trees, 29, 973-984, 2015.

Morton, D. C., Nagol, J., Carabajal, C. C., Rosette, J., Palace, M., Cook, B. D., Vermote, E. F., Harding, D. J., and North, P. R. J.: Amazon forests maintain consistent canopy structure and greenness during the dry season, Nature, 506, 7487, doi:10.1038/nature13006, 2014.

Myneni, R. B., Yang, W., Nemani, R. R., Huete, A. R., Dickinson, R. E., Knyazikhin, Y., Didan, K., Fu, R., Juarez, R. I. N., Saatchi, S. S., Hashimoto, H., Ichii, K., Shabanov, N. V., Tan, B., Ratana, P., Privette, J. L., Morisette, J. T., Vermote, E. F., Roy, D. P., Wolfe, R. E., Friedl, M. A., Running, S. W., Votava, P., ElSaleous, N., Devadiga, S., Su, Y., and Salomonson, V. V.: Large seasonal swings in leaf area of Amazon rainforests, P. Natl. Acad. Sci. USA, 104, 4820-4823, 2007.

Nepstad, D. and Moutinho, P.: LBA-ECO LC-14 Biophysical Measurements, Rainfall Exclusion, Tapajos National Forest, Data set, available at: http://daac.ornl.gov, from Oak Ridge National Laboratory Distributed Active Archive Center, Oak Ridge, Tennessee, USA, 2013.

O'Brien, J. J., Oberbauer, S. F., Clark, D. B., and Clark, D. A.: Phenology and stem diameter increment seasonality in a Costa Rican wet tropical forest, Biotropica, 40, 151-159, 2008.

Ohashi, S., Okada, N., Nobuchi, T., Siripatanadilok, S., and Veenin, T.: Detecting invisible growth rings of trees in seasonally dry forests in Thailand: isotopic and wood anatomical approaches, Trees-Struct. Funct., 23, 813-822, 2009.

Owusu-Sekyere, E., Cobbina, J., and Wakatsuki, T.: Nutrient cycling in primary, secondary forests and cocoa plantation in the Ashanti region, Ghana, West Afr. J. Appl. Ecol., 9, 1-9, 2006.

Pan, Y., Birdsey, R. A., Fang, J., Houghton, R., Kauppi, P. E., Kurz, W. A., Phillips, O. L., Shvidenko, A., Lewis, S. L., Canadell, J. G., Ciais, P., Jackson, R. B., Pacala, S. W., McGuire, A. D., Piao, S., Rautiainen, A., Sitch, S., and Hayes, D.: A Large and Persistent Carbon Sink in the World's Forests, Science, 333, 988 993, 2011

Pascal, J.-P.: Les forêts denses humides sempervirentes des Ghâts Occidentaux de l'Inde: écologie, structure, floristique, succession, Ph.D. thesis, Institut Français de Pondichéry, Inde, 1984.

Paula, S. A. D. and Lemos Filho, J. P. D.: Dinâmica do dossel em mata semidecidua no perimetro urbano de Belo Horizonte, MG, Braz. J. Botany, 24, 545-551, 2001.

Pelissier, R. and Pascal, J. P.: Two-year tree growth patterns investigated from monthly girth records using dendrometer bands in a wet evergreen forest in India, J. Trop. Ecol., 16, 429-446, 2000.

Prior, L., Bowman, D., and Eamus, D.: Seasonal differences in leaf attributes in Australian tropical tree species: family and habitat comparisons, Funct. Ecol., 18, 707-718, 2004.

Restrepo-Coupe, N., da Rocha, H. R., Hutyra, L. R., da Araujo, A. C., Borma, L. S., Christoffersen, B., Cabral, O. M. R., de Camargo, P. B., Cardoso, F. L., Lola da Costa, A. C., Fitzjarrald, D. R., Goulden, M. L., Kruijt, B., Maia, J. M. F., Malhi, Y. S., Manzi, A. O., Miller, S. D., Nobre, A. D., von Randow, C., Abreu Sa, L. D., Sakai, R. K., Tota, J., Wofsy, S. C., Zanchi, F. B., and Saleska, S. R.: What drives the seasonality of photosynthesis across the Amazon basin? A cross-site analysis of eddy flux tower measurements from the Brasil flux network, Agr. Forest Meteorol., 182, 128-144, 2013.

Roderstein, M., Hertel, D., and Leuschner, C.: Above- and belowground litter production in three tropical montane forests in southern Ecuador, J. Trop. Ecol., 21, 483-492, 2005.

Ross, M., Coultas, C., and Hsieh, Y.: Soil-productivity relationships and organic matter turnover in dry tropical forests of the Florida Keys, Plant Soil, 253, 479-492, 2003.

Rossatto, D. R., Hoffmann, W. A., and Franco, A. C.: Differences in growth patterns between co-occurring forest and savanna trees affect the forest-savanna boundary, Funct. Ecol., 23, 689-698, 2009.

Rowland, L., da Costa, A. C. L., Galbraith, D. R., Oliveira, R. S., Binks, O. J., Oliveira, A. A. R., Pullen, A. M., Doughty, C. E., Metcalfe, D. B., Vasconcelos, S. S., Ferreira, L. V., Malhi, Y., Grace, J., Mencuccini, M., and Meir, P.: Death from drought in tropical forests is triggered by hydraulics not carbon starvation, Nature, 528, 119-122, 2015.

Rowland, L., Hill, T. C., Stahl, C., Siebicke, L., Burban, B., Zaragoza-Castells, J., Ponton, S., Bonal, D., Meir, P., and Williams, M.: Evidence for strong seasonality in the carbon storage and carbon use efficiency of an Amazonian forest, Glob. Change Biol., 20, 979-991, 2014a.

Rowland, L., Malhi, Y., Silva-Espejo, J. E., Farfan-Amezquita, F., Halladay, K., Doughty, C. E., Meir, P., and Phillips, O. L.: The sensitivity of wood production to seasonal and interannual variations in climate in a lowland Amazonian rainforest, Oecologia, 174, 295-306, 2014b.

Rutishauser, E., Wagner, F., Herault, B., Nicolini, E.-A., and Blanc, L.: Contrasting above-ground biomass balance in a Neotropical rain forest, J. Veget. Sci., 21, 672-682, 2010.

Schöngart, J., Piedade, M., Ludwigshausen, S., Horna, V., and Worbes, M.: Phenology and stem-growth periodicity of tree species in Amazonian floodplain forests, J. Trop. Ecol., 18, 581597, 2002.

Schwarz, G.: Estimating the dimension of a model, Ann. Stat., 6, 461-464, 1978.

Sheil, D.: Growth assessment in tropical trees: large daily diameter fluctuations and their concealment by dendrometer bands, Can. J. Forest Res., 33, 2027-2035, 2003.

Stahl, C., Burban, B., Bompy, F., Jolin, Z., Sermage, J., and Bonal, D.: Seasonal variation in atmospheric relative humidity contributes to explaining seasonal variation in trunk circumference of tropical rain-forest trees in French Guiana, J. Trop. Ecol., 26 , 393-405, 2010.

Stocker, G. C., Thompson, W. A., Irvine, A. K., Fitzsimon, J. D., and Thomas, P. R.: Annual patterns of litterfall in a lowland and tableland rainforest in tropical Australia, Biotropica, 27, 412420, 1995.

Swaine, M., M., Lieberman, D., and Hall, J.: Structure and dynamics of a tropical dry forest in Ghana, Vegetatio, 88, 31-51, 1990.

Team, R. C.: R: A Language and Environment for Statistical Computing, R Foundation for Statistical Computing, Vienna, Austria, 2014.

Toledo, M. M., Sousa Paiva, E. A., Lovato, M. B., and de Lemos Filho, J. P.: Stem radial increment of forest and savanna ecotypes of a Neotropical tree: relationships with climate, phenology, and water potential, Trees-Struct. Funct., 26, 11371144, 2012. 
Toma, T.: Dendrometer data from Pasoh, FFPRI-Japan, 2012.

Trouet, V., Mukelabai, M., Verheyden, A., and Beeckman, H.: Cambial growth season of brevi-deciduous Brachystegia spiciformis trees from South Central Africa restricted to less than four months, PLoS ONE, 7, e47364, doi:10.1371/journal.pone.0047364, 2012.

van der Sleen, P., Groenendijk, P., Vlam, M., Anten, N. P. R., Boom, A., Bongers, F., Pons, T. L., Terburg, G., and Zuidema, P. A.: No growth stimulation of tropical trees by 150 years of $\mathrm{CO}_{2}$ fertilization but water-use efficiency increased, Nat. Geosci., 8, 24-28, 2015.

Vasconcelos, H. and Luizão, F.: Litter production and litter nutrient concentrations in a fragmented Amazonian landscape, Ecol. Appl., 14, 884-892, 2004.

Vieira, S., de Camargo, P. B., Selhorst, D., da Silva, R., Hutyra, L., Chambers, J. Q., Brown, I. F., Higuchi, N., dos Santos, J., Wofsy, S. C., Trumbore, S. E., and Martinelli, L. A.: Forest structure and carbon dynamics in Amazonian tropical rain forests, Oecologia, 140, 468-479, 2004.

Vincent, G.: Dendrometer data from IRD-World Agroforestry Center, 2012.

Wagner, F., Rossi, V., Stahl, C., Bonal, D., and Hérault, B.: Asynchronism in leaf and wood production in tropical forests: a study combining satellite and ground-based measurements, Biogeosciences, 10, 7307-7321, doi:10.5194/bg-10-7307-2013, 2013.

Wagner, F., Brede, B., Verbesselt, J., and L. E. O. C., A.: Correction of sun-sensor geometry effects from MODIS MCD43A1 product for tropical forest applications, in: Simposio Brasileiro de Sensoriamento Remoto, 17. (SBSR), Joao Pessoa, 2015.

Wagner, F., Rossi, V., Aubry-Kientz, M., Bonal, D., Dalitz, H., Gliniars, R., Stahl, C., Trabucco, A., and Hérault, B.: PanTropical Analysis of Climate Effects on Seasonal Tree Growth, PLOS ONE, 9, e92337, doi:10.1371/journal.pone.0092337, 2014.
Wieder, K. and Wright, J. S.: Tropical forest litter dynamics and dry season irrigation on Barro Colorado Island, Panama, Ecology, 76, 1971-1979, 1995.

Worbes, M.: Annual growth rings, rainfall-dependent growth and long-term growth patterns of tropical trees from the Caparo Forest Reserve in Venezuela, J. Ecol., 87, 391-403, 1999.

Wright, S. J. and Cornejo, F. H.: Seasonal Drought and Leaf Fall in a Tropical Forest., Ecology, 71, 1165-1175, 1990.

Wu, J., Albert, L. P., Lopes, A. P., Restrepo-Coupe, N., Hayek, M., Wiedemann, K. T., Guan, K., Stark, S. C., Christoffersen, B., Prohaska, N., Tavares, J. V., Marostica, S., Kobayashi, H., Ferreira, M. L., Campos, K. S., da Silva, R., Brando, P. M., Dye, D. G., Huxman, T. E., Huete, A. R., Nelson, B. W., and Saleska, S. R.: Leaf development and demography explain photosynthetic seasonality in Amazon evergreen forests, Science, 351, 972-976, 2016.

Wurth, M. K. R., Pelaez-Riedl, S., Wright, S. J., and Körner, C.: Non-structural carbohydrate pools in a tropical forest, Oecologia, 143, 11-24, 2005.

Zanne, A., Lopez-Gonzalez, G., Coomes, D., Ilic, J., Jansen, S., Lewis, S., Miller, R., Swenson, N., Wiemann, M., and Chave, J.: Data from: Towards a worldwide wood economics spectrum, Ecol. Lett., 12, 351-366, doi:10.5061/dryad.234, 2009.

Zanon, M. L. B. and Finger, C. A. G.: Relationship of meteorological variables with the growth of Araucaria angustifolia (Bertol.) Kuntze trees in implanted stands, Ciência Florestal, 20, 467-476, 2010.

Zhang, H., Yuan, W., Dong, W., and Liu, S.: Seasonal patterns of litterfall in forest ecosystem worldwide, Ecol. Complex., 20, 240247, 2014.

Zomer, R. J., Trabucco, A., Bossio, D. A., and Verchot, L. V.: Climate change mitigation: A spatial analysis of global land suitability for clean development mechanism afforestation and reforestation, Agr. Ecosyst. Environ., 126, 67-80, 2008. 